\title{
Biological impact of ultraviolet-B radiation on spider mites and its application in integrated pest management
}

\author{
Masahiro Osakabe ${ }^{1}$ (D)
}

Received: 3 October 2020 / Accepted: 13 December 2020 / Published online: 4 January 2021

(c) The Author(s) 2021

\begin{abstract}
Many plant-dwelling mites reside on lower leaf surfaces. The biological impact of solar ultraviolet-B (UV-B) radiation on spider mites has been demonstrated over the last decade. Due to the serious problem of acaricide resistance in spider mites, the development of alternative control methods and establishment of an integrated pest management (IPM) strategy are urgently needed, especially for greenhouse horticultural crops such as strawberries. A physical control method for spider mites using UV-B lamps (UV-B method) has been established. Using the UV-B method, simultaneous control of spider mites and powdery mildew, a major disease, is possible, making it is a favorable IPM strategy. Here, I introduce general findings regarding the biological impact of UV radiation on spider mites and phytoseiid mites, useful natural enemies for biological control, over the last decade, including dose response, effective wavelengths, and photoreactivation. Moreover, I introduce the application of UV-B to spider mite control in strawberry greenhouses, including the possibility of concurrent use with biological control via phytoseiid mites, and discuss its possible contributions to IPM.
\end{abstract}

Keywords UV damage $\cdot$ Photoreactivation $\cdot$ Tetranychus urticae $\cdot$ Neoseiulus californicus $\cdot$ Acari

\section{Introduction}

The near ultraviolet (UV) wavelengths are divided into UV-A (315-400 nm), UV-B (280-315 nm), and UV-C $(200-280 \mathrm{~nm})$. As UV-C and the majority of UV-B are absorbed by the atmosphere and ozone layer, solar UV radiation at ground level is composed of UV-A with a small proportion of UV-B. At shorter wavelengths, UV exerts stronger inhibition on organisms (Slieman and Nicholson 2000), resulting in a spectrum of biological activity of solar UV radiation that peaks in the range of 305-315 nm (Coohill and Sagripanti 2009; Munakata et al. 1996).

The biological impact of solar UV-B combined with the effects of climate change has heightened awareness of ozone layer destruction including the ozone hole in Antarctica (Ballaré et al. 2011; Bornman et al. 2019; Paul and GwynnJones 2003). Meanwhile, attenuation of solar UV-B radiation has resulted in an increase in herbivory by insects at high latitudes in both the southern and northern hemispheres

Masahiro Osakabe

osakabe.masahiro.2r@kyoto-u.ac.jp

1 Laboratory of Ecological Information, Graduate School of Agriculture, Kyoto University, Kyoto 606-8502, Japan
(Ballaré et al. 2001; Gwynn-Jones et al. 1997; Rousseaux et al. 2001, 2004). Conversely, enhanced UV-B radiation increases the deleterious effects on insect behavior and health and affects their interactions with plants via induction of defensive material production and photomorphogenic changes (Burdick et al. 2015; Caldwell et al. 2007; Escobar-Bravo et al. 2017; Kuhlmann and Müller 2009a, 2009b; Yin et al. 2018). Solar UV radiation is generally higher at lower latitudes, except in the ozone hole region, and has greater impacts on organisms living in low latitudes (Meador et al. 2009), leading to evolution of protective systems and other adaptations against ambient UV-B radiation in insects (Abram et al. 2015; Gaudreau et al. 2017).

Plant-dwelling mites frequently reside on the lower leaf surfaces of their host plants (Sudo and Osakabe 2011). In addition to topographic differences between adaxial (upper) and abaxial (lower) leaf surfaces (Chien and Sussex 1996; Price 1980; Sakai et al. 2012a; Sudo and Osakabe 2013), the preference for lower leaf surfaces by tiny mites (Jeppson 1975; Kiritani 2012, 2013) has been attributed to avoidance of harsh environments on upper leaf surfaces such as radiant heat (Lu et al. 2014; Perring et al. 1984), desiccation (Ferro and Chapman 1979; McEnroe 1961) and rain (Boyne and Hain 1983; Ho 2000; Osakabe 1965; Rêgo et al. 2013). 
Detrimental effects of solar UV-B on plant-dwelling mites and avoidance of these effects by occupying lower leaf surfaces on sunny days have been reported previously by Barcelo (1981). Over the last decade, numerous studies have revealed significant biological impacts of UV-B radiation on plant-dwelling mites (Ohtsuka and Osakabe 2009; Suzuki et al. 2009). Genus Tetranychus, which includes the twospotted spider mite T. urticae Koch (Acari: Tetranychidae), comprises the most important spider mites acting as horticultural pests because of their vigorous fertility, extremely broad host range, and development of acaricide resistance worldwide (Jeppson 1975; Osakabe et al. 2009; Van Leeuwen et al. 2010, 2015). Therefore, the use of UV-B (as well as UV-C) for spider mite control has raised interest (Short et al. 2018; Tanaka et al. 2016).

Below, I review the biological impacts and adaptations of herbivorous spider mites and their natural enemy, phytoseiid mites. Then, I introduce the challenges associated with application of UV-B lamps for spider mite management in greenhouses and discuss the potential contribution of UV-B technology to integrated pest management (IPM) strategies for greenhouse cultivation.

\section{Hiding from solar radiation}

\section{The majority of mites use lower leaf surfaces}

Tetranychus urticae pierces both adaxial and abaxial leaf surfaces with its stylet (Bensoussan et al. 2016). In field observations by Osakabe et al. (2006), 99\% of T. urticae females resided on lower (abaxial) leaf surfaces in an apple orchard from mid-June to early-August in Hiraka, Akita, Japan (39 $\left.23^{\prime} \mathrm{N}, 140^{\circ} 3^{\prime} \mathrm{E}\right)$. Ohtsuka and Osakabe (2009) revealed that egg hatching and juvenile development were significantly suppressed on upper (adaxial) leaf surfaces or on leaf discs that were placed under UV-transparent film, while most eggs hatched and larvae developed on lower (abaxial) leaf surfaces or on leaf discs that were placed under UV-attenuating film. Plants accumulate UV-B-absorbing compounds, including leaf phenolics (e.g., flavonoids), in epidermal cells that reduce UV-B penetration via protection of sensitive targets in mesophyll cells, possibly acting as selective sunscreens for small arthropods on the lower leaf surfaces (Izaguirre et al. 2007; Lavola et al. 1998; Rousseaux et al. 2004; Tegelberg et al. 2004). Similar protective effects of host plant leaves have been demonstrated in the UV-sensitive freshwater snail Planorbarius corneus (Linnaeus) (Wahl 2008).

Several practical observations provide evidence that mites avoid solar UV radiation. For example, movement of T. urticae females from the upper to lower leaf surfaces of host plants under solar radiation was accelerated when covered by UV-transparent film overhead compared with UV-opaque film (Sakai and Osakabe 2010). Conversely, movement from the lower to upper leaf surfaces of host plants covered by UV-opaque film overhead was accelerated after the lower leaf surfaces were irradiated with reflected solar UV radiation (Sakai and Osakabe 2010). On the other hand, in a UV irradiation experiment with a wavelength interval of $20 \mathrm{~nm}$ using a spectroscopic light source, Sakai and Osakabe (2010) found that $T$. urticae did not escaped from leaf area irradiated with UV-B and UV-A at 300 and $360 \mathrm{~nm}$ wavelengths, while it escaped from the area irradiated with UV-A at 320 and $340 \mathrm{~nm}$ wavelengths. Based on this result, they supposed that T. urticae avoids UV-A at 320-340 nm wavelengths in the sun, thereby avoiding UV-B contained in it at the same time (Sakai and Osakabe 2010). Monochromatic analyses by Suzuki et al. (2009) also showed avoidance behavior by $T$. urticae females more often in the presence of UV-A $(350 \mathrm{~nm})$ than UV-B $(300 \mathrm{~nm})$. Tetranychus urticae females showed a maximum behavioral response along with a second peak at $375-525 \mathrm{~nm}$ wavelengths (Naegele et al. 1966). In contrast, Suzuki et al. (2013) showed that T. urticae avoids entering patches illuminated with UV-B $\left(\lambda_{\max } 307 \mathrm{~nm}\right)$ from a light emitting diode under virtual field conditions provided by a micro-locomotion compensator, which is an equipment to keep and record a walking mite in an experimental area by complementing the movement of mites on the test table with the movement of the table (Kojima et al. 2003). Therefore, it is controversial how $T$. urticae avoids solar UV-B.

In addition to $T$. urticae, the eyeless predacious phytoseiid mite Neoseiulus californicus (McGregor) (Acari: Phytoseiidae) avoids areas irradiated with solar UV (Tachi and Osakabe 2012). Neoseiulus californicus escapes rapidly from areas irradiated with monochromatic UV-B radiation at wavelengths $\geq 300 \mathrm{~nm}$, in contrast to $T$. urticae (Tachi and Osakabe 2014). If the complicated thread webs produced by spider mites (prey) are present, $N$. californicus does not escape from areas irradiated with UV at $\geq 310 \mathrm{~nm}$, whereas it escapes areas irradiated with dangerous UV-B at $300 \mathrm{~nm}$ (see section "Fatal wavelengths") (Tachi and Osakabe 2014). Phytoseiid mites show escape behavior even from visible light (VIS) (Tachi and Osakabe 2012; Weintraub et al. 2007), causing them to remain on lower leaf surfaces and within domatia (Ghazy et al. 2016; Onzo et al. 2009, 2010).

\section{The minority of mites use upper leaf surfaces}

In contrast to many other mites, spider mites in the genus Panonychus (Acari, Tetranychidae) frequently occupy upper leaf surfaces (Foott 1963; Jones and Parrella 1984; Morimoto et al. 2006; Osakabe et al. 2006). Eggs of the citrus red mite Panonychus citri (McGregor) (Acari: Tetranychidae) show greater resistance to UV-B radiation 
than do those of T. urticae (Fukaya et al. 2013; Osakabe et al. 2006). The herbivorous false spider mite, Brevipalpus obovatus Donnadieu (Acari: Tenuipalpidae), is another occupier of upper leaf surface (Sudo and Osakabe 2011), and it shows greater UV-B resistance than $P$. citri (Sudo and Osakabe 2015). Sudo and Osakabe (2013) suggested that $B$. obovatus has a reduced risk of egg predation by phytoseiid mites such as Phytoseius nipponicus Ehara (Acari: Phytoseiidae), present on the lower leaf surfaces of Viburnum erosum Thunb. var. punctatum Franch. et Sav. (Adoxaceae), by ovipositing on the upper leaf surfaces (Sudo and Osakabe 2013). However, it is difficult for B. obovatus eggs to survive on upper leaf surfaces in summer due to strong detrimental effects of both UV-B radiation and radiant heat from the sun, limiting the field occurrence of this mite to autumn (Sudo and Osakabe 2015).

UV irradiation and radiant heat from the sun both induce the formation of reactive oxygen species (ROS), which cause oxidative damage in organisms, such as lipid peroxidation (Girotti 1985, 1998) as well as DNA base damage (Cadet and Wagner 2013). Although the protective effects of enzymatic antioxidant responses have not been clarified (Yang et al. 2010), P. citri possesses astaxanthin, an efficient scavenger of ROS (Camera et al. 2009), as its main pigment (Atarashi et al. 2017; Metcalf and Newell 1962). Atarashi et al. (2017) observed a higher survival rate at high temperature in wild type than albino $P$. citri, which lacks astaxanthin, although no difference was detected under UV-B irradiation. On the other hand, summer-form Tetranychus mites also possess astaxanthin but the distribution of astaxanthin is restricted to the mites' eye spots; when they enter diapause, ketocarotenoids including astaxanthin are synthesized and accumulate throughout the body (Kawaguchi et al. 2016; Veerman 1972, 1974a). As a result, Tetranychus mites have increased UV resistance in their diapause form than in their summer form (Suzuki et al. 2009).

Panonychus ulmi Koch (Acari: Tetranychidae) exhibits a reddish body and egg coloration similar to P. citri, likely due to carotenoids such as astaxanthin or complexes thereof (Putman 1965). Generally, Panonychus mites are inferior competitors to Tetranychus mites, as the complicated webs of fine threads created by the latter significantly inhibit the activity and development of the former (Morimoto et al. 2006). Field observations in an apple orchard revealed that $P$. ulmi females tended to avoid lower leaf surfaces on which $T$. urticae was present and to move to the competitor-free upper leaf surfaces (Osakabe et al. 2006). Solar radiation may have non-negligible effects on the evolution and seasonal dynamics of plant-dwelling mites via the effects of oxidative stressors, namely UV-B radiation and radiant heat.

\section{Seasonal differences in the biological impacts of solar UV-B radiation}

In general, the UV-B irradiation intensity and daily cumulative dose of solar radiation are high in summer and low in winter. Therefore, we tend to assume that the biological impact of solar UV-B radiation is strongest in summer. However, a semi-field experiment performed in Kyoto, Japan, from spring (mid-April) to autumn (end of October) revealed the highest ovicidal effect of solar UV radiation on T. urticae eggs in spring (Sakai et al. 2012b). The hatchability of eggs exposed to solar UV radiation (placed under UV-transparent film) was lowest in April (10.7\%) and increased toward October (74.9-92.3\%). In contrast, the hatchability of eggs placed under UV-opaque film was 96.2-99.8\% throughout the experimental period from spring to autumn (Sakai et al. $2012 \mathrm{~b}$ ), indicating a strong impact of solar UV radiation on spider mites. Sakai et al. (2012b) found a negative correlation between the hatchability of eggs exposed to solar UV radiation and the cumulative UV-B dose during the egg period.

From the data reported by Sakai et al. (2012b), the $\mathrm{LD}_{50}$ value of solar UV-B radiation for T. urticae eggs was estimated as $\sim 50 \mathrm{~kJ} / \mathrm{m}^{2}$, which is equivalent to the cumulative irradiation dose over 3 days in April or October or $<2.5$ days in summer (June-August) in Kyoto. The reason for the peak mortality of eggs in spring (April) and the minimum mortality in autumn (October) remain unclear. However, it is likely that the higher temperature in autumn shortened the egg period and thereby reduced the cumulative UV-B dose received during the egg period in autumn relative to spring. If this speculation is true, the combined effect of UV-B dose and temperature is an important factor for identifying the optimal conditions for practical UV-B control of spider mites.

The effect of temperature on UV damage to organisms remains controversial (see section "Effects of air temperature on mite mortality due to daily nighttime UV-B irradiation"), and in particular, the impacts of global climate change are largely unknown (Alton and Franklin 2012, 2017). In Japan, the temperature increase in 2015-2018 relative to 1981-2010 was greater in spring than in autumn (Fig. 1). Such meteorological changes may influence the seasonal occurrence of spider mites via both the effect of temperature on developmental rate and UV damage mitigation.

\section{Fatal effects and reciprocity law}

\section{Fatal wavelengths}

The fatal effects of solar UV-B radiation on T. urticae were shown by Ohtsuka and Osakabe (2009). In the sun, 


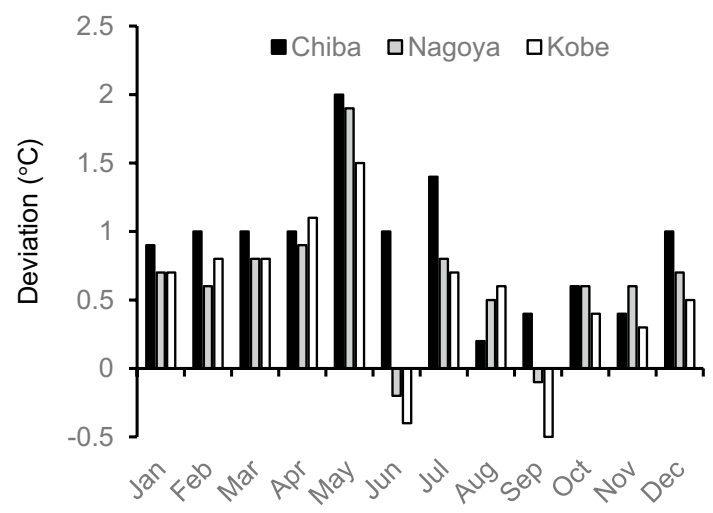

Fig. 1 Deviation of monthly mean temperature in 2015-2018 from that in 1981-2010. Data from the Japan Meteorological Agency (https://www.data.jma.go.jp/gmd/cpd/cgi-bin/view/index.php)

egg hatching and juvenile development were significantly suppressed on the upper (adaxial) leaf surfaces, while most eggs hatched, and larvae on lower (abaxial) leaf surfaces or under UV-attenuating film developed normally. Experiments on the effects of single-wavelength acute irradiation using artificial monochromatic UV radiation indicated that the extent of damage changed dramatically between wavelengths of $300 \mathrm{~nm}$ and longer; all eggs of T. urticae and $N$. californicus died from exposure to $300 \mathrm{~nm}$ wavelength while all eggs hatched upon exposure to $310 \mathrm{~nm}$ and longer wavelengths in N. californicus (Tachi and Osakabe 2014) and $320 \mathrm{~nm}$ and longer wavelengths in T. urticae ( $310 \mathrm{~nm}$ has not been tested) (Sakai and Osakabe 2010). A similar response has been reported in marine zooplankton (Copepoda) eggs (Kouwenberg et al. 1999b). UV-C causes greater damage to spider mites (Suzuki et al. 2009), but solar radiation at wavelength below $290 \mathrm{~nm}$ scarcely reaches ground level. Meanwhile, UV-A shows no lethal effects on mites (Ohtsuka and Osakabe 2009; Sakai and Osakabe 2010; Suzuki et al. 2009; Tachi and Osakabe 2014). Therefore, the wavelengths fatal to mites lie within a very narrow range $(290-300 \mathrm{~nm})$ that accounts for a small portion of the total solar radiation at ground level.

\section{Reciprocity law in the lethal effect}

Several studies have been conducted on aquatic organisms to determine the mechanism of UV damage. Reciprocity might be applicable to the mortality of shrimp zoea (Wübben 2000), sea urchin (early stages; Nahon et al. 2009), and fish eggs (Kouwenberg et al. 1999a). However, divergence from reciprocity was observed at low UV-B radiation in shrimp zoea and several aquatic animals (Cywinska et al. 2000; Wübben 2000), and thus the applicability of the reciprocity law to UV damage in those organisms remains questionable. In contrast, mortality due to UV-B irradiation is strictly determined by the cumulative UV-B dose (=UV-B irradiance $\left[\mathrm{W} / \mathrm{m}^{2}\right] \times$ irradiation time $\left.[\mathrm{s}]\right)$ in T. urticae (Murata and Osakabe 2013). Moreover, Murata and Osakabe (2013) found strong linear regression between mortality probit and the log-transformed UV-B dose, which was useful for determining $\mathrm{LD}_{50}$ values of $0.58,1.19,1.01$, and $26.12 \mathrm{~kJ} / \mathrm{m}^{2}$ for the egg, larva, teleiochrysalis, and adult female, respectively. Egg production by females decreased linearly, and the developmental duration from larvae to adult emergence increased linearly, with increasing cumulative UV-B dose (Murata and Osakabe 2013). Murata and Osakabe (2013) performed these experiments in a laboratory illuminated by fluorescent lights. Therefore, UV-B damage may be underestimated compared to dark conditions due to effects of photoreactivation discussed in "DNA lesions and repair" section. The UV damage in this spider mite generally followed the reciprocity law, suggesting that the effect of UV-B application on spider mite management will be predictable.

The large difference in $\mathrm{LD}_{50}$ values between the laboratory experiment using a UV-B lamp and the semi-field experiment under solar UV radiation (86-fold greater; Sakai et al. 2012b) described above is noteworthy. In the laboratory experiment, eggs were illuminated with a moderate-intensity fluorescent lamp (Murata and Osakabe, 2013), whereas the amount of VIS in the natural sunlight was overwhelming. This difference in the $\mathrm{LD}_{50}$ values may be explained by photoreactivation efficiency, as described below.

\section{Stage-specific vulnerability to UV-B damage}

UV-B sensitivity of eggs varies among developmental stages; for example, Atlantic cod eggs are vulnerable during post-fertilization (mid-gastrulation) and hatching stages in comparison with the middle embryonic stages (Kouwenberg et al. 1999a). The UV-B vulnerability of T. urticae eggs peaks at $24-48 \mathrm{~h}$ after oviposition at $25{ }^{\circ} \mathrm{C}$ (Murata and Osakabe 2014; Yoshioka et al. 2018), corresponding to when the larval body is formed based on the germinal disk (Dearden et al. 2002). Then, the UV-B tolerance of the eggs increases, reaching a maximum just prior to hatching (Murata and Osakabe 2014). Neoseiulus californicus eggs show their highest UV-B vulnerability at similar embryonic development periods as those of T. urticae eggs (Sugioka et al. 2018). Interestingly, the goldfish Carassius auratus (L.) embryo shows a similar time course of sensitivity and resistance to UV-B as that of mites (Wiegand et al. 2004).

The high UV-B resistance of mature embryos just before hatching is related to the fact that most $T$. urticae larvae irradiated with UV-B do not die immediately, and instead enter the protochrysalis stage (Murata and Osakabe 2017b). The damaged larvae die during the protochrysalis stage or molting (Murata and Osakabe 2014, 2017b), indicating the 
vulnerability of the chrysalis stage. This finding is supported by the smaller $\mathrm{LD}_{50}$ of the teleiochrysalis than that of larvae, although adult $T$. urticae females may have higher values than those of larvae due to their larger body size, as described above (Murata and Osakabe 2013). Interestingly, greater numbers of quiescent stage European red mites, Panonychus ulmi (Koch), occupied lower leaf surfaces than upper leaf surfaces, as reported by Foott (1963). Similarly, many larvae and nymphs of $P$. citri reside on the lower surfaces of citrus leaves, despite higher juvenile development rates and egg production levels in females, indicating a nutritional advantage of residing on the upper leaf surface (Fukaya et al. 2013).

\section{DNA lesions and repair}

\section{Accumulation of DNA damage}

Ambient UV-B radiation frequently causes DNA lesions in organisms in the forms of cyclobutane pyrimidine dimers (CPDs), (6-4) photoproducts (6-4 PPs), and their Dewar valence isomers, which interrupt the processes of gene transcription and replication (Cadet et al. 2012; Pfeifer 2020; Rastogi et al. 2010; Sinha and Häder 2002). Although 6-4 PPs may have more serious lethal effects on organisms due to the formation of DNA bends, CPDs are more common and therefore responsible for most cytotoxic effects (Mitchell and Nairn 1989; Sinha and Häder 2002).

Studies on Daphnia and bacteria suggest that DNA lesions accumulate in a dose-dependent manner (Connelly et al. 2009; Riley and Kaufman 1972). Murata and Osakabe (2017a) observed increased mortality and simultaneous accumulation of DNA lesions (CPDs and 6-4 PPs) with increasing UV-B doses in irradiated T. urticae larvae. The levels of CPDs and 6-4 PPs are linearly correlated with the UV-B dose (Murata and Osakabe 2017a).

\section{DNA repair systems}

Nucleotide excision repair (NER) and photoenzymatic repair (PER) are the major repair systems for DNA lesions in organisms (Rastogi et al. 2010; Sinha and Häder 2002; Thoma 1999; Weber 2005). Multiple enzymes act in NER to replace damaged DNA with undamaged nucleotides, using ATP for energy (Sinha and Häder 2002). In contrast, PER is a relatively simple repair system in which DNA lesions are directly repaired by photolyases using energy from blue light (400-450 nm wavelength) and UV-A (Kalthoff 1975; Sancar 2003; Shiroya et al. 1984; Sinha and Häder 2002). The $T$. urticae genome includes four highly homologous copies of the CPD photolyase gene (tetur $12 \mathrm{~g} 04440$, tetur $12 \mathrm{~g} 04460$, tetur $35 \mathrm{~g} 00010$, and tetur $35 \mathrm{~g} 00030$ ), the product of which repairs CPDs, but it contains no gene encoding a (6-4) photolyase for repairing 6-4 PPs (Grbić et al. 2011), which has been found in limited organisms, such as Drosophila (Todo et al. 1996). A single-copy gene encoding the xeroderma pigmentosum group A protein (tetur05g03450), one of the core factors for NER, is present in the T. urticae genome (Grbić et al. 2011; Murata and Osakabe 2017a). Murata and Osakabe (2017a) suggested that UV-B-induced 6-4PPs disappeared 1 day after UV-B irradiation in T. urticae larvae kept in the dark. Thus, 6-4 PPs may be repaired by mechanisms other than PER including NER in T. urticae.

\section{Recovering from fatal UV-B damage using light energy}

Photoreactivation via repair of DNA lesions such as CPDs and 6-4 PPs via PER is essential, and the reactivation system is present in a wide range of organisms, including bacteria (Ikenaga et al. 1970; Peccia and Hernandez 2001), rotifers (Grad et al. 2003), crustaceans (Connelly et al. 2009; Damkaer and Dey 1983; Grad and Williamson 2001), algae (Pakker et al. 2000; Pescheck 2019), plants (Hada et al. 2003; Kaiser et al. 2009; Manova et al. 2016; Takahashi et al. 2002), amphibians (Blaustein et al. 1994; Morison et al. 2020), and fishes (Applegate and Ley 1988; Lawrence et al. 2020; Mitchell et al. 2009; Wiegand et al. 2004), but not in placental mammals, which may rely on other repair systems: base excision repair, NER, and so on (Sinha and Häder 2002). In spider mites, Santos (2005) observed photoreactivation of UV-B damage in T. urticae, the mortality rate of $T$. urticae adult females irradiated with UV-B at $46.8 \mathrm{~kJ} / \mathrm{m}^{2}$ was reduced from $46 \%$ (when kept in the dark after UV-B irradiation) to $26 \%$ with VIS illumination after UV-B irradiation. As the adult female is the most resistant to UV-B radiation, more dramatic photoreactivation effects are observed egg and larval stages. UV-B-irradiated T. urticae eggs and larvae recovered at rates of $57 \%$ and $~ 100 \%$ with subsequent VIS radiation (Murata and Osakabe 2014).

In a midge Smittia sp. (Chironomidae, Diptera) and a bacterium Escherichia coli (Migula) (Enterobacteriaceae, Enterobacterales), VIS intensity has been suggested as a factor that affects the efficiency of photoreactivation (Kalthoff et al. 1978; Kelner 1951). In contrast, correlation of the photoreactivation efficiency with the cumulative VIS irradiance after UV-B irradiation has been reported in the long-nosed potoroo Potorous tridactylus (Kerr) (Potoroidae, Diprotodontia) and a bacterium Streptomyces griseus (Krainsky) (Streptomycetaceae, Actinomycetales) (Chiang and Rupert 1979; Kelner 1951). Murata and Osakabe (2014) suggested that the photoreactivation of $T$. urticae also depends on the cumulative VIS irradiation (a reciprocity law), though the regression curve was analyzed by a nonlinear least-squares method. 


\section{Efficient wavelengths for photoreactivation}

For activation of PER, radiation at wavelengths of 350-450 nm generally provides an effective energy source (Baalen and O'Donnell 1972; Chiang and Rupert 1979; Kalthoff et al. 1978; Kelner 1951; Sancar 2003). Murata and Osakabe (2014) assessed the effects of UV-A and wavelength-filtered VIS (blue, green, yellow, and red) on photoreactivation of $T$. urticae eggs. They estimated the effective radiation range as UV-A to green light ( $\leq 500 \mathrm{~nm}$ ) (Murata and Osakabe 2014), roughly corresponding to those of other organisms. Intensification of solar UV-B radiation occurs later than UV-A (morning) and is negligible earlier in the evening (Fig. 2). Because lower leaf surfaces also exposed to low-intensity UV-B rays scattered in the air, survival rate and egg production of Typhlodromalus aripo De Leon, the most UV-B vulnerable phytoseiid mite species, decrease on lower leaf surfaces when the leaves are irradiated with UV-B (Onzo et al. 2010). UV-A and visible lights also seem to be scattered in shadows such as lower leaf surfaces frequently. Thus, solar radiation in the early morning and late evening may enhance the recovery from UV damage via photoreactivation in mites.

\section{Application of UV-B for mite control in strawberry greenhouses}

Spider mites have long been major pests affecting strawberry production in Japan (Aida 1987; Yanagita 2019). Moreover, the recent development of acaricide resistance in $T$. urticae has become a serious problem in Japanese strawberry greenhouses, hindering the selection of chemicals for rotation spraying (Yamamoto 2012; Yanagita 2019). Therefore, the development of alternative control technologies is urgently needed. The UV-B method (Tanaka et al. 2016) may be a promising addition to IPM in greenhouse strawberry cultivation.

\section{UV-B ray delivery to lower leaf surfaces}

Along with many other plant-dwelling mites, most T. urticae individuals reside on the lower leaf surfaces of host plants in the field (Osakabe et al. 2006). Thus, for practical use of UV-B for spider mite control in strawberry greenhouses, UV-B delivery to the lower leaf surfaces on which spider mites reside is important. For this reason, Tanaka et al. (2016) used a combination of overhead UV-B lamps and light-reflecting sheets in a strawberry greenhouse. The light-reflecting sheet was a flash-spun nonwoven fabric sheet (Tyvek 700AG; DuPont-Asahi Flash Spun Products, Tokyo, Japan), which diffusely reflected solar radiation, including UV-A and UV-B, and VIS with high efficiency (>90\%; Sakai and Osakabe 2010). As a result, the UV-B radiation was $0.023-0.053 \mathrm{~W} / \mathrm{m}^{2}$ on the lower leaf surface and $1.61-1.87 \mathrm{~W} / \mathrm{m}^{2}$ on the upper leaf surface of greenhouse strawberry plants (Tanaka et al. 2016). For the reasons described in the following section, UV-B irradiation was performed at midnight every day for $3 \mathrm{~h}$. Therefore, the daily cumulative irradiation on the lower leaf surfaces was $0.25-0.57 \mathrm{~kJ} / \mathrm{m}^{2}$.

UV-B irradiation affects plant-dwelling arthropods and pathogens not only directly, but also through indirect pathways involving plant responses to UV irradiation, such as the accumulation of phenolic compounds (Escobar-Bravo et al. 2017; Neugart and Schreiner 2018) and the induction of protective signaling systems (Ballaré 2014; Kunz et al. 2006). In strawberries, UV-B irradiation induces disease resistance and strongly prevents the development of powdery mildew caused by Sphaerotheca aphanis (Wallroth) Braun var. aphanis (Erysiphales: Erysiphaceae) (Kanto et al. 2009). Although the effects of plant defense systems on spider mites have been reported (Kant et al. 2008; Ozawa et al. 2017), indirect effects of UV-B radiation acting through host plants on spider mites have not been reported to date. Tomimori et al. (2020) detected no effect of pre-irradiation with UV-B on the perilla plants Perilla frutescens (L.) Britton var. crispa (Thunb.) H. Deane (Lamiales: Lamiaceae), which produces abundant essential oil containing various
Fig. 2 Daily fluctuations of solar UV-A (solid line) and UV-B (gray line) in Kyoto, Japan on a 25 April, b 21 July, and $\mathbf{c} 7$ October in 2010. Data from the Solar Radiation and Weather Monitoring Project at Kyoto Women's University (34 $59^{\prime} \mathrm{N}, 135^{\circ} 47^{\prime} \mathrm{E}$; http:// db.cger.nies.go.jp/gem/ja/uv/ uv_sitedata/kyoto/index.html)
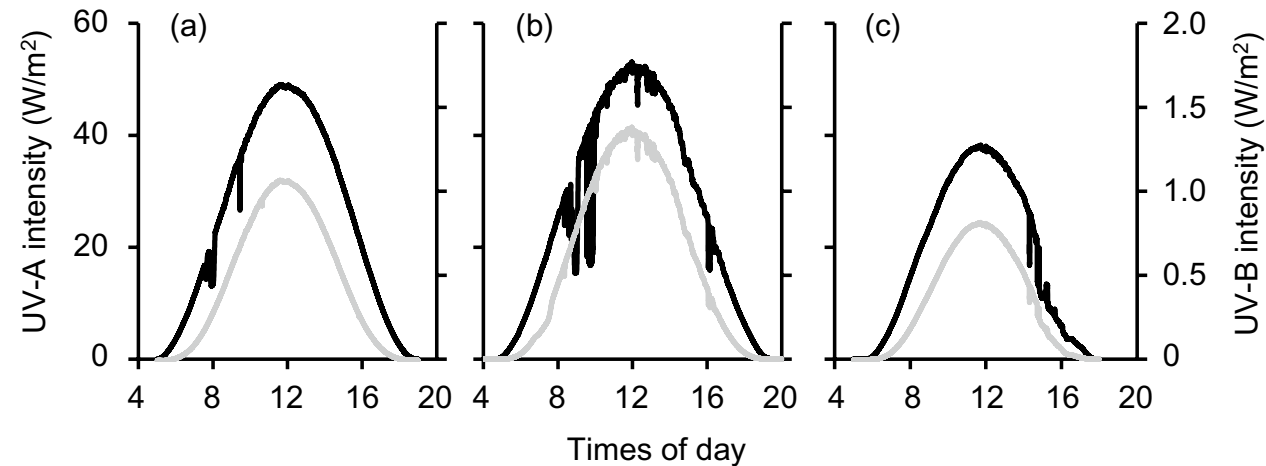
secondary metabolites that act as a biological protective mechanism, on the juvenile development and egg production of T. urticae. This highlights the importance of delivery of UV-B rays to spider mite locations for practical application.

\section{Diminished photoreactivation by midnight UV-B irradiation}

Suzuki et al. (2014) and Koveos et al. (2017) showed that simultaneous white light and UV-B irradiation reduced the mortality of Tetranychus spider mite eggs and phytoseiid mite eggs caused by UV-B damage. The photoreactivation efficiency increased with increasing cumulative VIS irradiation, as did the reciprocity effect on the accumulation of UV-B damage (Murata and Osakabe 2014). These results indicate less effective control of spider mites by UV-B irradiation during the daytime; therefore, nighttime irradiation is preferred in greenhouses (Masui et al. 2013; Tanaka et al. 2016).

Moreover, increasing lag time between UV-B irradiation and light irradiation for photoreactivation reduces the photoreactivation efficiency in T. urticae eggs, and a lag longer than $4 \mathrm{~h}$ inactivates the photoreactivation system (Murata and Osakabe 2014; Yoshioka et al. 2018). In contrast, no effect of lag time was observed in UV-B-exposed larvae; even after a 4-h lag, all larvae exposed to photoreactivation light developed to adulthood, but no larvae developed if they were not exposed to light (Murata and Osakabe 2014). Therefore, the effect of UV-B irradiation on controlling spider mites in greenhouse production might be due to an ovicidal mechanism.

\section{Concurrent use of UV-B and biological control}

\section{Reversal of vulnerability to UV-B between spider mites and phytoseiid mites under daily nighttime irradiation for practical application}

According to egg mortality after a single period of acute UV-B irradiation, phytoseiid mites appear to be more vulnerable to UV-B damage than spider mites (Ghazy et al. 2016; Tachi and Osakabe 2012). Interestingly, it was recently reported that resistance to daily UV-B irradiation at midnight is higher in $N$. californicus eggs than T. urticae eggs (Nakai et al. 2018; Yuan and Osakabe 2020). Yuan and Osakabe (2020) found a linear regression between the logarithmic daily cumulative level of UV-B radiation and probit mortality in $T$. urticae eggs $\left(y=6.54 x+11.7, R^{2}=0.867\right.$, $\left.P=4.38 \times 10^{-3}\right)$ and $N$. californicus eggs $(y=6.99 x+8.76$, $R^{2}=0.978, P=1.17 \times 10^{-4}$ ) in laboratory experiments that simulated practical UV-B irradiation conditions in strawberry greenhouses (Tanaka et al. 2016). The $\mathrm{LD}_{50}$ value of $N$. californicus eggs was $0.29 \mathrm{~kJ} /\left(\mathrm{m}^{2}\right.$ day $)$ at $25{ }^{\circ} \mathrm{C}$, which was three times higher than that in T. urticae $\left(0.095 \mathrm{~kJ} /\left(\mathrm{m}^{2}\right.\right.$ day); $25{ }^{\circ} \mathrm{C}$ ). The mortality of eggs irradiated with 0.15 , 0.17 , and $0.2 \mathrm{~kJ} /\left(\mathrm{m}^{2}\right.$ day $)$ were estimated from the regression lines as 90, 95, and 98\%, respectively, in T. urticae and 2, 5, and $15 \%$, respectively, in $N$. californicus. Therefore, cumulative irradiation in the range of $0.15-0.2 \mathrm{~kJ} / \mathrm{m}^{2}$ $\left(0.014-0.019 \mathrm{~W} / \mathrm{m}^{2}\right.$ for $3 \mathrm{~h} /$ day) is advantageous for applying UV-B for spider mite control in combination with $N$. californicus at $25^{\circ} \mathrm{C}$. However, Nakai et al. (2018) reported that a UV-B dose of $0.27 \mathrm{~kJ} /\left(\mathrm{m}^{2}\right.$ day $)$ at $25^{\circ} \mathrm{C}$ reduced the developmental success of hatched $N$. californicus larvae, indicating that lower UV-B doses within the cumulative radiation range may be preferable for controlling spider mites using phytoseiid mites.

The mechanism behind the difference in the UV-B vulnerability of spider mites and phytoseiid mites between a single UV-B irradiation and daily nighttime UV-B irradiation remains unclear. Koveos et al. (2017) reported higher hatchability under continuous UV-B irradiation without VIS irradiation in the eggs of four of phytoseiid mite species compared with $T$. urticae eggs. Considering the reciprocity of UV-B-induced mortality (Murata and Osakabe 2013), the difference in vulnerability could be attributed to the shorter egg duration of phytoseiid mites relative to spider mites. Moreover, variations in UV-B vulnerability among the embryonic developmental stages (Murata and Osakabe 2014; Sugioka et al. 2018; Yoshioka et al. 2018) may be involved. This topic may be related to the interaction between UV damage and temperature and thus linked to the issue of global climate change.

\section{Effects of air temperature on mite mortality caused by daily} nighttime UV-B irradiation

Laboratory experiments revealed that daily nighttime UV-B irradiation in greenhouses is more effective for controlling spider mites at low than high temperatures (Nakai et al. 2018; Yuan and Osakabe 2020). Mortality of T. urticae eggs caused by UV-B irradiation at $0.097 \mathrm{~kJ} /\left(\mathrm{m}^{2}\right.$ day $)$ was 7.0 , 28.6 , and $78.2 \%$ at 30,25 , and $18{ }^{\circ} \mathrm{C}$, respectively (Yuan and Osakabe 2020). The air temperatures (monthly average) $0.15 \mathrm{~m}$ above a ridge in greenhouse reported by Tanaka et al. (2016) in Hyogo Prefecture, Japan (34.9 $\left.{ }^{\circ} \mathrm{N}, 134.9^{\circ} \mathrm{E}\right)$ were lower than $18^{\circ} \mathrm{C}$ from December to April, and reached 21-22. $6^{\circ} \mathrm{C}$ in May, indicating that the cumulative radiation on lower leaf surfaces was sufficient for control of T. urticae eggs.

Like T. urticae, the biological impact of daily nighttime irradiation on $N$. californicus is stronger at relatively low temperature. The rates of egg mortality caused by UV-B irradiation at $0.27 \mathrm{~kJ} /\left(\mathrm{m}^{2}\right.$ day $)$ were $13.7,31.1$, and $80.3 \%$ at 30,25 , and $18{ }^{\circ} \mathrm{C}$, respectively (Yuan and Osakabe 2020). Analyzing the relationship between temperature and probit 
mortality by linear regression, strong correlations $\left(R^{2}>0.95\right)$ were detected in both $T$. urticae and $N$. californicus eggs (Fig. 3). The regression line was similar between $N$. californicus $\mathrm{UV}-\mathrm{B}$ irradiated at $0.27 \mathrm{~kJ} /\left(\mathrm{m}^{2}\right.$ day $)$ and T. urticae UV-B irradiated at $0.097 \mathrm{~kJ} /\left(\mathrm{m}^{2}\right.$ day $)$, indicating that $N$. californicus eggs have stronger resistance to daily nighttime UV-B irradiation than do T. urticae eggs, at least within the temperature range of $18-30{ }^{\circ} \mathrm{C}$. Moreover, in the winter, daily cumulative UV-B radiation for spider mite control can be reduced, and this reduction is beneficial for the activity of phytoseiid mites. Vulnerability to UV-B radiation varies among phytoseiid mite species (Ghazy et al. 2016; Onzo et al. 2010). Phytoseiulus persimilis Athias-Henriot is more resistant to UV-B radiation compared with other phytoseiids that are potential biological control agents, such as $N$. californicus, Neoseiulus womersleyi Schicha, and Amblyseius swirskii Athias-Henriot (Koveos et al. 2017; Tachi and Osakabe 2012). Phytoseiulus persimilis eggs show orange-red color that might be due to keto-carotenoids derived from prey spider mites (Veerman 1974b), while eggs of Neoseiulus phytoseiid mites are colorless or milky white. Keto-carotenoids, especially astaxanthin, has strong antioxidant activity (Camera et al. 2009), and have the effects reducing lipid peroxidation in spider mites (Atarashi et al. 2017). According to Croft et al. (1999), eggs of P. persimilis is larger in size (egg length: $0.24 \mathrm{~mm}$ ) than that of Neoseiulus species (egg length: $0.20-0.21 \mathrm{~mm}$ ), being advantageous in terms of UV-B resistance due to limitation of penetration. Moreover, according to Escudero and Ferragut (2005), egg duration of $P$. persimilis at $25{ }^{\circ} \mathrm{C}(1.4-1.8$ days) is shorter

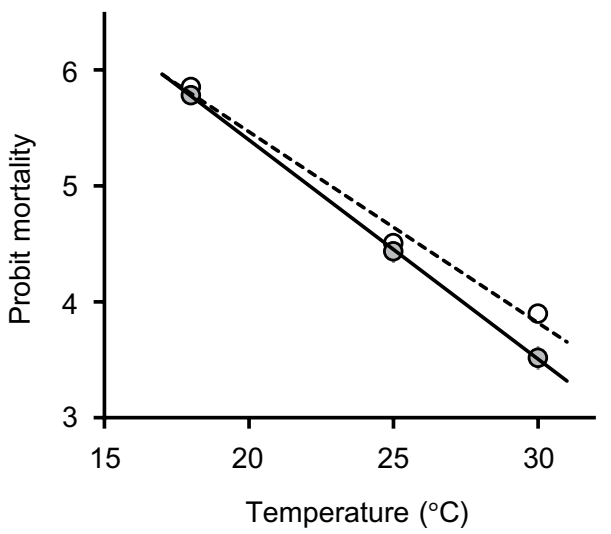

Fig. 3 Correlation of probit mortality with temperature in the eggs of Tetranychus urticae (gray circles) and Neoseiulus californicus (open circles) irradiated with 0.097 and $0.27 \mathrm{~kJ} /\left(\mathrm{m}^{2}\right.$ day), respectively. Regression lines: $y=-1.65 x+8.76, R^{2}=0.95, P=5.32 \times 10^{-6}$ for $T$. urticae (solid line) and $y=-1.89 x+9.18, R^{2}=0.979, P=2.69 \times 10^{-7}$ for $N$. californicus (broken line). This graph was created using the data from Yuan and Osakabe (2020) than that of $N$. californicus (1.9-2.4 days), though the effects on UV-B resistance is not clear so far.

Although a clear relationship between mortality and temperature was seen in mite eggs after daily nighttime UV-B irradiation, the thermal dependence of UV-B damage in various organisms remains controversial. UV damage in $E$. coli and tadpoles of the frog Limnodynastes peronii Duméril and Bibron is greater at lower temperature than at higher temperature (Mangoli et al. 2014; Van Uitregt et al. 2007). The cladoceran Daphnia catawba Coker and the calanoid copepod Leptodiaptomus minutus Lilljeborg show greater UV-B resistance with increasing temperature, whereas the rotifer Asplanchna girodi de Guerne shows reduced resistance at higher temperatures (Williamson et al. 2002). Moreover, in four Daphnia species, DNA repair occurs more rapidly at lower temperatures, but the opposite pattern is seen in Daphnia pulicaria Forbes (MacFadyen et al. 2004). Enzymes associated with DNA repair and ROS scavenging likely have high activity within the optimal temperature range. The studies described above suggest the involvement of multiple factors, such as developmental stage and timing of gene expression. In spider mites, some stages are specifically vulnerable, such as developing embryo and quiescent juvenile (Murata and Osakabe 2014, 2017b; Sugioka et al. 2018; Yoshioka et al. 2018). Research in the association of such stage-specific UV-B vulnerability with variation in the thermal dependence of UV damage will be worthwhile for elucidating adaptation to UV-B radiation in mites.

\section{Differences in the behavioral responses of spider mites and phytoseiid mites to UV-B irradiation}

Tachi and Osakabe (2012) showed that most $T$. urticae and $N$. californicus individuals escaped from solar UV radiation within 30 and $10 \mathrm{~min}$, respectively. In laboratory experiments using monochromatic UV radiation, however, T. urticae females responded by escaping from UV-A irradiation at 320 and $340 \mathrm{~nm}$ wavelengths, but not from UV-B irradiation at $300 \mathrm{~nm}$ (Sakai and Osakabe 2010). In a monochromatic analysis by Suzuki et al. (2009), non-diapausing T. urticae females also escaped from safe UV-A radiation $(350 \mathrm{~nm})$ more often than from lethal UV-B radiation $(300 \mathrm{~nm})$. Barcelo and Calkins (1980) and Barcelo (1981) showed strong dose-dependent responses of $T$. urticae escape from leaf areas irradiated with UV-B at the beginning of experiments. Then, the mite distribution between areas with and without UV-B radiation became constant at $\sim 2 \mathrm{~h}$ after the start of UV-B irradiation (Barcelo and Calkins 1980). On the other hand, Suzuki et al. (2013) revealed that T. urticae increased the frequency of turning behavior when it entered an area irradiated with monochromatic UV-B (307 nm) using a virtual field system, suggesting that $T$. urticae perceives 
UV-B radiation visually, as thrips (Mazza et al. 2010), or via another mechanism, as phytoseiid mites.

Although phytoseiid mites are eyeless, they escape from solar UV radiation more quickly than spider mites (Tachi and Osakabe 2012). Photoreceptors distributing brains have been known in a wide range of classes of nonmammalian vertebrates (Bertolucci and Foà 2004). In insects, multiple extraocular photoreceptive areas including brains and genitalia have been reported (Arikawa et al. 1980; Spaethe and Briscoe 2005). Elucidation of extraocular photoreceptor in the eyeless phytoseiid mites is interesting but not yet so far.

The arresting effects of spider mite webs on predacious phytoseiid mites have long been known. When phytoseiid mites encounter the webs or their remnants, they walk slowly and turn frequently, entering a "search mode" for their prey, spider mites (Hoy and Smilanick 1981). This behavior may result in the phytoseiid mite trailing silks or residues left by dispersed spider mites (Shinmen et al. 2010; Yano and Osakabe 2009). In the experiments performed in Kyoto City, Japan $\left(35^{\circ} \mathrm{N}, 136^{\circ} \mathrm{E}\right)$ from 7 September to 8 October, 2011, females of $N$. californicus escaped from solar VIS radiation (Tachi and Osakabe 2012) as well as from artificially provided monochromatic UV-A and UV-B radiation (Tachi and Osakabe 2014). They are also arrested by residue from T. urticae females (web and eggs), even when irradiated with monochromatic UV of wavelength $\geq 310 \mathrm{~nm}$, which is not harmful to $N$. californicus (Tachi and Osakabe 2014). In contrast, they escaped quickly from an area irradiated with harmful UV-B at $300 \mathrm{~nm}$, regardless of the presence of spider mite residue (Tachi and Osakabe 2014), indicating that phytoseiid mites perceive this deleterious UV radiation. Interestingly, prey eggs without webs do not arrest $N$. californicus females in UV-irradiated areas (Tachi and Osakabe 2014), showing the importance of webs in their behavioral response to predation (Furuichi et al. 2005). I suppose that phytoseiid mites likely escape and hide more quickly than spider mites when UV-B lamps are turned on in a greenhouse. Spider mites flee to and are saved in a safe place, such as the shadows on host plant leaves, which phytoseiid mites possibly enter to escape from UV-B irradiation. Consequently, the phytoseiid mite may efficiently forage on prey in these hidden areas in a greenhouse subjected to UV irradiation.

\section{Potential protection of phytoseiid mites from UV-B irradiation by pollen feeding}

The removal of ROS by antioxidants is generally considered a UV protective mechanism. However, protection via the ROS-scavenging effects of antioxidants has been tested mainly in vitro (Camera et al. 2009; Kootstra 1994), and the effects of antioxidants on the survival of organisms under ambient UV radiation remain vague (Heath et al. 2013).
Indeed, diapausing T. urticae females, which are more resistant to UV-B radiation than the summer form of this species (Suzuki et al. 2009), accumulate keto-carotenoids such as astaxanthin, a very powerful ROS scavenger (Kawaguchi et al. 2016; Veerman 1974a). This suggests that the carotenoid composition and dose affect their survival under ambient UV-B radiation. In phytoseiid mites, Nakai et al. (2018) found that $N$. californicus eggs and hatched larvae produced by females feeding on P. citri, which contains abundant astaxanthin, were more resistant to UV-B radiation than those produced by females feeding on T. urticae.

Plant pollen is a possible alternative food for many phytoseiid mites (Castagnoli and Simoni 1999; Kishimoto et al. 2014; Osakabe 1988; Osakabe et al. 1987). The germ cells contained in pollen must be protected from ambient UV-B, and therefore, pollen contains UV-B-protective compounds (Feng et al. 2000; Wang et al. 2010; Žilić et al. 2014). Sugioka et al. (2018) identified tri-coumaroylspermidine and catechins as the major antioxidants in peach pollen and tea pollen, respectively. Neoseiulus californicus females fed pollen showed increased survivorship after exposure to artificial UV-B irradiation, and the viability of eggs produced by pollen-fed females was higher than that of T. urticae-fed females (Sugioka et al. 2018). The transmission of those antioxidants into eggs has not been proven unfortunately. However, I consider that such transmission is not surprising, because transmission of dietary obtained carotenoids, which is essential for diapause induction, from mother to eggs is known for a long time in phytoseiid mites and spider mites (Van Zon et al. 1981; Veerman 1980, 1992).

Later, Yuan et al. (2020) identified five types of hydroxycinnamoyl spermidine derivatives in strawberry pollen. The majority of the content was comprised of three derivatives containing a caffeoyl group or both caffeoyl and feruloyl groups (Yuan et al. 2020). The caffeoyl and feruloyl groups confer higher antioxidant capacity than does the coumaroyl group in spermidine derivatives (Castelluccio et al. 1995; Shahidi and Chandrasekara 2010). Yuan et al. (2020) observed the development of juveniles including egg periods on strawberry pollen was faster than that on T. urticae and found enhanced survival of females and hatching of eggs in $N$. californicus after UV-B irradiation combined with a strawberry pollen diet. This finding may help maintain $N$. californicus within strawberry greenhouses equipped with UV-B lamps.

\section{UV-B lamps as an IPM strategy in greenhouses}

One advantage of UV technology in IPM is that it enables simultaneous control of spider mites and powdery mildew, both of which are economically important pests of 
strawberry (Kanto et al. 2009, 2011, 2014; Sugeno et al. 2018) and wide range of horticultural crops including rose (Kobayashi et al. 2013; Suthaparan et al. 2012) and cucumber (Suthaparan et al. 2014, 2017). Powdery mildew fungi have developed resistance to a wide range of fungicides due to their frequent application (Elderfield et al. 2018; Nakano et al. 1992; Sombardier et al. 2010; Wyenandt et al. 2018).

A comparison of UV damage and photoreactivation between mites and powdery mildew fungi drawn from the literature is provided in Table 1. The UV-B wavelength range that can effectively suppress infection by powdery mildew fungi is less than $310 \mathrm{~nm}$ (Suthaparan et al. 2012, 2016a). The effect of UV-B at 290-310 nm on powdery mildew fungi depends on the duration of exposure (Suthaparan et al. 2016a). The effectiveness of UV-B by direct irradiation rather than by indirect effects by UV-B via host plants, decreasing photoreactivation with lag time between UV-B irradiation and VIS irradiation in powdery mildew fungi (Janisiewicz et al. 2016a; Suthaparan et al. 2012, 2016b, 2018) are similar to those in spider mites. Janisiewicz et al. (2016b) reported a similar decrease in photoreactivation with lag time in the gray mold fungus Botrytis cinerea Pers. These similarities in symptoms and protective responses to UV-B radiation between spider mites and fungi are advantageous for the development of IPM strategies against both pests. The mechanism by which the time lag between UV-B irradiation and VIS radiation diminishes photoreactivation capacity is currently under investigation.
UV-C radiation (wavelength $\leq 280 \mathrm{~nm}$ ) strongly inhibits fungal development (Janisiewicz et al. 2016a; Suthaparan et al. 2016a) as well as T. urticae population growth (Short et al. 2018). However, irradiation at a wavelength of $280 \mathrm{~nm}$ inhibits the walking ability of both $N$. californicus and T. urticae in an intensity-dependent manner (Sakai and Osakabe 2010; Tachi and Osakabe 2014). The proportions of $N$. californicus females incapable of walking normally (i.e., of escaping from UV) after UV radiation at $280 \mathrm{~nm}$ wavelength were $95.1 \%$ (37/39 우), $100 \%$ (41/41 우우) and $0 \%(0 / 28$ 웅) at intensities of $1.26,0.73$ and $0.29 \mathrm{~W} / \mathrm{m}^{2}$, respectively (Tachi and Osakabe 2014). The intensity of UV-C (254 nm) used by Short et al. (2018) for T. urticae control was $0.237 \mathrm{~W} / \mathrm{m}^{2}$. Although this is lower than the intensity that caused no damage to phytoseiid mite behavior at $280 \mathrm{~nm}$, the shorter wavelength might have a greater effect on the behavior and health of phytoseiid mites. Conversely, the benefit of UV-C is the short irradiation time required for control of spider mites. The T. urticae population was suppressed by only $60 \mathrm{~s}$ of irradiation per day (Short et al. 2018). Therefore, information about the interaction between UV-C and phytoseiid mites is likely to be helpful for supporting the practical application of UV-C. In the future, it is worth considering how each UV wavelength can be optimized for IPM.

Table 1 Comparison of UV damage and photoreactivation between mites and fungi causing powdery mildew

\begin{tabular}{|c|c|c|c|}
\hline UV effects & $\begin{array}{l}\text { Spider mite } \\
\text { and phytoseiid } \\
\text { mite }\end{array}$ & Powdery mildew fungus & References \\
\hline Direct (D) and indirect (I) effects & $\mathrm{D}>\mathrm{I}$ & $\mathrm{D}>\mathrm{I}$ & $\begin{array}{l}\text { Ohtsuka and Osakabe (2009), Suthaparan } \\
\text { et al. (2012, 2016b, 2018), Janisiewicz } \\
\text { et al. (2016a), Tomimori et al. (2020) }\end{array}$ \\
\hline Deleterious wavelength & $<310 \mathrm{~nm}$ & $<310 \mathrm{~nm}$ & $\begin{array}{l}\text { Sakai and Osakabe (2010), Tachi and } \\
\text { Osakabe (2014), Suthaparan et al. } \\
\text { (2016a) }\end{array}$ \\
\hline Reciprocity in deleterious effects & Yes & $\begin{array}{l}\text { Effects depend on duration of exposure } \\
\text { (UV-B) }\end{array}$ & $\begin{array}{l}\text { Tachi and Osakabe (2012), Murata and } \\
\text { Osakabe (2013), Suthaparan et al. } \\
\text { (2016a), Yuan and Osakabe (2020) }\end{array}$ \\
\hline Photoreactivation from UV damage & Yes & Yes & $\begin{array}{l}\text { Murata and Osakabe (2014, 2017a), } \\
\text { Janisiewicz et al. (2016b), Koveos et al. } \\
\text { (2017), Nakai et al. (2018), Sugioka } \\
\text { et al. (2018), Suthaparan et al. (2018) }\end{array}$ \\
\hline $\begin{array}{l}\text { Effective wavelength for photoreactiva- } \\
\text { tion }\end{array}$ & $\begin{array}{l}\text { From UV-A } \\
\text { to green } \\
\text { ( } \leq 500 \mathrm{~nm} ; \\
\text { T. urticae })\end{array}$ & $350-500 \mathrm{~nm}$ (Olidium neolycopersici) & $\begin{array}{l}\text { Murata and Osakabe (2014), Suthaparan } \\
\text { et al. (2018) }\end{array}$ \\
\hline $\begin{array}{l}\text { Dark period after UV irradiation to } \\
\text { invalid photoreactivation }\end{array}$ & $\geq 4 \mathrm{~h}$ & $>4 \mathrm{~h}$ & $\begin{array}{l}\text { Murata and Osakabe (2014), Janisiewicz } \\
\text { et al. (2016a), Suthaparan et al. (2018), } \\
\text { Yoshioka et al. (2018) }\end{array}$ \\
\hline
\end{tabular}




\section{Future perspectives}

The UV-B method is a control technique that exploits the behaviors and physiologies of spider mites related to UV adaptation to exploit their weaknesses. Although increased shadowing due to plant growth may reduce the effectiveness of this method, phytoseiid mites avoiding UV-B may prey on spider mites surviving in the shadows. Consequently, the UV-B method can suppress overgrowth of the spider mite population in excess of the control capacity of phytoseiid mites, and phytoseiid mites can complement the weakness of the UV-B method in shaded areas. Moreover, nighttime UV-B irradiation allows workers to avoid unwanted exposure to UV-B. Thus, the concurrent use of the UV-B method and biological control is an extremely promising management method.

On the other hand, the physiological processes of UV damage and adaptation to it in spider mites require more works. Mites are organisms with a remarkable life-anddeath reaction to UV damage, making them an ideal subject for study of the mechanism of UV adaptation.

Acknowledgements These works were supported by JSPS KAKENHI Grant Numbers 22380036 and 26292029 and by Cabinet Office, Government of Japan, Cross-ministerial Strategic Innovation Promotion Program (SIP), "Technologies for creating next-generation agriculture, forestry and fisheries" (funding agency: Bio-oriented Technology Research Advancement Institution, NARO). I appreciate Honorary Prof. Hideo Konami of Kyoto Women's University who kindly provided the observation data of solar UV radiation.

Open Access This article is licensed under a Creative Commons Attribution 4.0 International License, which permits use, sharing, adaptation, distribution and reproduction in any medium or format, as long as you give appropriate credit to the original author(s) and the source, provide a link to the Creative Commons licence, and indicate if changes were made. The images or other third party material in this article are included in the article's Creative Commons licence, unless indicated otherwise in a credit line to the material. If material is not included in the article's Creative Commons licence and your intended use is not permitted by statutory regulation or exceeds the permitted use, you will need to obtain permission directly from the copyright holder. To view a copy of this licence, visit http://creativecommons.org/licenses/by/4.0/.

\section{References}

Abram PK, Guerra-Grenier E, Després-Einspenner M-L, Ito S, Wakamatsu K, Boivin G, Brodeur J (2015) An insect with selective control of egg coloration. Curr Biol 25:2007-2011. https://doi.org/10.1016/j.cub.2015.06.010

Aida K (1987) Tolerable pest density of two-spotted spider mite, Tetranychus urticae Koch (Acarina: Tetranychidae) on forcing culture strawberry, "Nyoho." Bull Tochigi Agr Exp Stn 33:41-46

Alton LA, Franklin CE (2012) Do high temperatures enhance the negative effects of ultraviolet-B radiation in embryonic and larval amphibians? Biol Open 1:897-903. https://doi.org/10.1242/ bio. 2012950

Alton LA, Franklin CE (2017) Drivers of amphibian declines: effects of ultraviolet radiation and interactions with other environmental factors. Clim Chang Responses 4:6. https://doi.org/10.1186/ s40665-017-0034-7

Applegate LA, Ley RD (1988) Ultraviolet radiation-induced lethality and repair of pyrimidine dimers in fish embryos. Mutat Res 198:85-92. https://doi.org/10.1016/0027-5107(88)90043-7

Arikawa K, Eguchi E, Yoshida A, Aoki K (1980) Multiple extraocular photoreceptive areas on genitalia of butterfly Papilio xuthus. Nature 288:700-702. https://doi.org/10.1038/288700a0

Atarashi M, Manabe Y, Kishimoto H, Sugawara T, Osakabe M (2017) Antioxidant protection by astaxanthin in the citrus red mite (Acari: Tetranychidae). Environ Entomol 46:1143-1150. https ://doi.org/10.1093/ee/nvx121

Baalen CV, O'Donnell R (1972) Action spectra for ultraviolet killing and photoreactivation in the blue-green alga Agmenellum quadruplicatum. Photochem Photobiol 15:269-274. https://doi. org/10.1111/j.1751-1097.1972.tb07331.x

Ballaré CL (2014) Light regulation of plant defense. Annu Rev Plant Biol 65:335-363. https://doi.org/10.1146/annurev-arplant-05021 3-040145

Ballaré CL, Rousseauxa MC, Searles PS, Zaller JG, Giordano CV, Robson TM, Caldwell MM, Sala OE, Scopel AL (2001) Impacts of solar ultraviolet-B radiation on terrestrial ecosystems of Tierra del Fuego (southern Argentina). An overview of recent progress. J Photochem Photobiol B 62:67-77. https://doi.org/10.1016/ S1011-1344(01)00152-X

Ballaré CL, Caldwell MM, Flint SD, Robinson SA, Bornman JF (2011) Effects of solar ultraviolet radiation on terrestrial ecosystems. Patterns, mechanisms, and interactions with climate change. Photochem Photobiol Sci 10:226-241. https://doi.org/10.1039/ C0PP90035D

Barcelo JA (1981) Photoeffects of visible and ultraviolet radiation on the two-spotted spider mite, Tetranychus urticae. Photochem Photobiol 33:703-706. https://doi.org/10.1111/j.1751-1097.1981. tb05477.x

Barcelo JA, Calkins J (1980) The kinetics of avoidance of simulated solar UV radiation by two arthropods. Biophys J 32:921-930. https://doi.org/10.1016/S0006-3495(80)85026-0

Bensoussan N, Santamaria ME, Zhurov V, Diaz I, Grbić M, Grbić V (2016) Plant-herbivore interaction: dissection of the cellular pattern of Tetranychus urticae feeding on the host plant. Front Plant Sci 7:1105. https://doi.org/10.3389/fpls.2016.01105

Bertolucci C, Foà A (2004) Extraocular photoreception and circadian entrainment in nonmammalian vertebrates. Chronobiol Int 21:501-519. https://doi.org/10.1081/CBI-120039813

Blaustein AR, Hoffman PD, Hokit G, Kiesecker JM, Walls SC, Hays JB (1994) UV repair and resistance to solar UV-B in amphibian eggs: a link to population declines? Proc Natl Acad Sci USA 91:1791-1795. https://doi.org/10.1073/pnas.91.5.1791

Bornman JF, Barnes PW, Robson TM, Robinson SA, Jansen MA, Ballaré CL, Flint SD (2019) Linkages between stratospheric ozone, UV radiation and climate change and their implications for terrestrial ecosystems. Photochem Photobiol Sci 18:681-716. https ://doi.org/10.1039/C8PP90061B

Boyne JV, Hain FP (1983) Effects of constant temperature, relative humidity, and simulated rainfall on development and survival of the spruce spider mite (Oligonychus ununguis). Can Entomol 115:93-105. https://doi.org/10.4039/Ent11593-1

Burdick SC, Prischmann-Voldseth DA, Harmon JP (2015) Density and distribution of soybean aphid, Aphis glycines Matsumura (Hemiptera: Aphididae) in response to UV radiation. Popul Ecol 57:457-466. https://doi.org/10.1007/s10144-015-0501-6 
Cadet J, Wagner JR (2013) DNA base damage by reactive oxygen species, oxidizing agents, and UV radiation. Cold Spring Harb Perspect Biol 5:a012559. https://doi.org/10.1101/cshperspec t.a012559

Cadet J, Mouret S, Ravanat J-L, Douki T (2012) Photoinduced damage to cellular DNA: direct and photosensitized reactions. Photochem Photobiol 88:1048-1065. https://doi.org/10.111 1/j.1751-1097.2012.01200.x

Caldwell MM, Bornman JF, Ballaré CL, Flint SD, Kulandaivelu G (2007) Terrestrial ecosystems, increased solar ultraviolet radiation, and interactions with other climate change factors. Photochem Photobiol Sci 6:252-266. https://doi.org/10.1039/B7000 19G

Camera E, Mastrofrancesco A, Fabbri C, Daubrawa F, Picardo M, Sies H, Stahl W (2009) Astaxanthin, canthaxanthin and $\beta$-carotene differently affect UVA-induced oxidative damage and expression of oxidative stress-responsive enzymes. Exp Dermatol 18:222231. https://doi.org/10.1111/j.1600-0625.2008.00790.x

Castagnoli M, Simoni S (1999) Effect of long-term feeding history on functional and numerical response of Neoseiulus californicus (Acari: Phytoseiidae). Exp Appl Acarol 23:217-234. https://doi. org/10.1023/A:1006066930638

Castelluccio C, Paganga G, Melikian N, Bolwell GP, Pridham J, Sampson J, Rice-Evans C (1995) Antioxidant potential of intermediates in phenylpropanoid metabolism in higher plants. FEBS Lett 368:188-192. https://doi.org/10.1016/0014-5793(95)00639-Q

Chiang T, Rupert CS (1979) Action spectrum for photoreactivation of ultraviolet irradiated marsupial cells in tissue culture. Photochem Photobiol 30:525-528. https://doi. org/10.1111/j.1751-1097.1979.tb07173.x

Chien JC, Sussex IM (1996) Differential regulation of trichome formation on the adaxial and abaxial leaf surfaces by gibberellins and photoperiod in Arabidopsis thaliana (L.) Heynh. Plant Physiol 111:1321-1328. https://doi.org/10.1104/pp.111.4.1321

Connelly SJ, Moeller RE, Sanchez G, Mitchell DL (2009) Temperature effects on survival and DNA repair in four freshwater cladoceran Daphnia species exposed to UV radiation. Photochem Photobiol 85:144-152. https://doi.org/10.1111/j.1751-1097.2008.00408.x

Coohill TP, Sagripanti J-L (2009) Bacterial inactivation by solar ultraviolet radiation compared with sensitivity to $254 \mathrm{~nm}$ radiation. Photochem Photobiol 85:1043-1052. https://doi.org/10.111 1/j.1751-1097.2009.00586.x

Croft BA, Luh HK, Schausberger P (1999) Larval size relative to larval feeding, cannibalism of larvae, egg or adult female size and larval-adult setal patterns among 13 phytoseiid mite species. Exp Appl Acarol 23:599-610. https://doi.org/10.1023/A:10062 36310613

Cywinska A, Crump D, Lean D (2000) Influence of UV radiation on four freshwater invertebrates. Photochem Photobiol 72:652659. https://doi.org/10.1562/0031-8655(2000)0720652IOU ROF2.0.CO2

Damkaer DM, Dey DB (1983) UV damage and photoreactivation potentials of larval shrimp, Pandalus platyceros, and adult euphausiids, Thysanoessa raschii. Oecologia 60:169-175. https ://doi.org/10.1007/BF00379518

Dearden PK, Donly C, Grbić M (2002) Expression of pair-rule gene homologues in a chelicerate: early patterning of two-spotted spider mite Tetranychus urticae. Development 129:5461-5472. https://doi.org/10.1242/dev.00099

Elderfield JAD, Lopez-Ruiz FJ, van den Bosch F, Cunniffe NJ (2018) Using epidemiological principles to explain fungicide resistance management tactics: Why do mixtures outperform alternations? Phytopathology 108:803-817. https://doi.org/10.1094/PHYTO -08-17-0277-R

Escobar-Bravo R, Klinkhamer PGL, Leiss KA (2017) Interactive effects of UV-B light with abiotic factors on plant growth and chemistry, and their consequences for defense against arthropod herbivores. Front Plant Sci 8:278. https://doi.org/10.3389/ fpls.2017.00278

Escudero LA, Ferragut F (2005) Life-history of predatory mites Neoseiulus californicus and Phytoseiulus persimilis (Acari: Phytoseiidae) on four spider mite species as prey, with special reference to Tetranychus evansi (Acari: Tetranychidae). Biol Control 32:378-384. https://doi.org/10.1016/j.biocontrol.2004.12.010

Feng H, An L, Tan L, Hou Z, Wang X (2000) Effect of enhanced ultraviolet-B radiation on pollen germination and tube growth of 19 taxa in vitro. Environ Exp Bot 43:45-53. https://doi.org/10.1016/ S0098-8472(99)00042-8

Ferro DN, Chapman RB (1979) Effects of different constant humidities and temperatures on twospotted spider mite egg hatch. Environ Entomol 8:701-705. https://doi.org/10.1093/ee/8.4.701

Foott WH (1963) Competition between two species of mites. II. Factors influencing intensity. Can Entomol 95:45-57. https://doi. org/10.4039/Ent9545-1

Fukaya M, Uesugi R, Ohashi H, Sakai Y, Sudo M, Kasai A, Kishimoto H, Osakabe M (2013) Tolerance to solar ultraviolet-B radiation in the citrus red mite, an upper surface user of host plant leaves. Photochem Photobiol 89:424-431. https://doi.org/10.1111/ php. 12001

Furuichi H, Yano S, Takafuji A, Osakabe M (2005) Prey preference of the predatory mite Neoseiulus womersleyi Schicha is determined by spider mite webs. J Appl Entomol 129:336-339. https://doi. org/10.1111/j.1439-0418.2005.00978.x

Gaudreau M, Abram PK, Brodeur J (2017) Host egg pigmentation protects developing parasitoids from ultraviolet radiation. Oikos 126:1419-1427. https://doi.org/10.1111/oik.04217

Ghazy NA, Osakabe M, Negm MW, Schausberger P, Gotoh T, Amano H (2016) Phytoseiid mites under environmental stress. Biol Control 96:120-134. https://doi.org/10.1016/j.biocontrol .2016 .02 .017

Girotti AW (1985) Mechanisms of lipid peroxidation. J Free Radic Biol Med 1:87-95. https://doi.org/10.1016/0748-5514(85)90011-X

Girotti AW (1998) Lipid hydroperoxide generation, turnover, and effector action in biological systems. J Lipid Res 39:1529-1542 (PMID: 9717713)

Grad G, Williamson CE (2001) Zooplankton survival and reproduction responses to damaging UV radiation: a test of reciprocity and photoenzymatic repair. Limnol Oceanogr 46:584-591. https:// doi.org/10.4319/lo.2001.46.3.0584

Grad G, Burnett BJ, Williamson CE (2003) UV damage and photoreactivation: timing and age are everything. Photochem Photobiol 78:225-227. https://doi.org/10.1562/0031-8655(2003)07802 25UDAPTA2.0.CO2

Grbić M, Van Leeuwen T, Clark RM, Rombauts S, Rouzé P, Grbić V, Osborne EJ, Dermauw W, Ngoc PCT, Ortego F, HernándezCrespo P, Diaz I, Martinez M, Navajas M, Sucena É, Magalhães S, Nagy L, Pace RM, Djuranović S, Smagghe G, Iga M, Christiaens O, Veenstra JA, Ewer J, Villalobos RM, Hutter JL, Hudson SD, Velez M, Yi SV, Zeng J, Pires-daSilva A, Roch F, Cazaux M, Navarro M, Zhurov V, Acevedo G, Bjelica A, Fawcett JA, Bonnet E, Martens C, Baele G, Wissler L, Sanchez-Rodriguez A, Tirry L, Blais C, Demeestere K, Henz SR, Gregory TR, Mathieu J, Verdon L, Farinelli L, Schmutz J, Lindquist E, Feyereisen R, Van de Peer Y (2011) The genome of Tetranychus urticae reveals herbivorous pest adaptations. Nature 479:487-492. https://doi. org/10.1038/nature10640

Gwynn-Jones D, Lee JA, Callaghan TV (1997) Effects of enhanced UV-B radiation and elevated carbon dioxide concentrations on a sub-arctic forest heath ecosystem. Plant Ecol 128:243-249. https ://doi.org/10.1007/978-94-011-5718-6_22

Hada H, Hidema J, Kaekawa M, Kumagai T (2003) Higher amounts of anthocyanins and UV-absorbing compounds effectively 
lowered CPD photorepair in purple rice (Oryza sativa L.). Plant Cell Environ 26:1691-1701. https://doi.org/10.104 6/j.1365-3040.2003.01087.x

Heath JJ, Cipollini DF, Stireman JO III (2013) The role of carotenoids and their derivatives in mediating interactions between insects and their environment. Arthropod Plant Interact 7:1-20. https:// doi.org/10.1007/s11829-012-9239-7

Ho C (2000) Spider-mite problems and control in Taiwan. Exp Appl Acarol 24:453-462. https://doi.org/10.1023/A:1006443619632

Hoy M, Smilanick JM (1981) Non-random prey location by the phytoseiid predator Metaseiulus occidentalis: differential responses to several spider mite species. Entomol Exp Appl 29:241-253. https://doi.org/10.1111/j.1570-7458.1981.tb03065.x

Ikenaga M, Patrick MH, Jagger J (1970) Action of photoreactivating light on pyrimidine heteroadduct in bacteria. Photochem Photobiol 11:487-494. https://doi.org/10.1111/j.1751-1097.1970. tb06019.x

Izaguirre MM, Mazza CA, Svatoš A, Baldwin IT, Ballaré CL (2007) Solar ultraviolet-B radiation and insect herbivory trigger partially overlapping phenolic responses in Nicotiana attenuata and Nicotiana longiflora. Ann Bot 99:103-109. https://doi. org/10.1093/aob/mcl226

Janisiewicz WJ, Takeda F, Nichols B, Glenn DM, Jurick WM II, Camp MJ (2016a) Use of low-dose UV-C irradiation to control powdery mildew caused by Podosphaera aphanis on strawberry plants. Can J Plant Pathol 38:430-439. https://doi. org/10.1080/07060661.2016.1263807

Janisiewicz WJ, Takeda F, Glenn DM, Camp MJ, Jurick WM II (2016b) Dark period following UV-C treatment enhances killing of Botrytis cinerea conidia and controls gray mold of strawberries. Phytopathology 106:386-394. https://doi. org/10.1094/PHYTO-09-15-0240-R

Jeppson LR (1975) Population ecology. In: Jeppson JR, Keifer HH, Baker EW (eds) Mites injurious to economic plants. University of California Press, Berkeley, pp 17-46

Jones VP, Parrella MP (1984) Intratree regression sampling plans for the citrus red mite (Acari: Tetranychidae) on lemons in southern California. J Econ Entomol 77:810-813. https://doi. org/10.1093/jee/77.3.810

Kaiser G, Kleiner O, Beisswenger C, Batschauer A (2009) Increased DNA repair in Arabidopsis plants overexpressing CPD photolyase. Planta 230:505-515. https://doi.org/10.1007/s0042 5-009-0962-y

Kalthoff K (1975) Compensation for solar UV damage by solar radiation of longer wavelengths. Oecologia 18:101-110. https://doi. org/10.1007/BF00348091

Kalthoff K, Urban K, Jäckle H (1978) Photoreactivation of RNA in UV-irradiated insect eggs (Smittia sp., Chironomidae, Diptera). II. Evidence for heterogeneous light-dependent repair activities. Photochem Photobiol 27:317-322. https://doi. org/10.1111/j.1751-1097.1978.tb07606.x

Kant MR, Sabelis MW, Haring MA, Schuurink RC (2008) Intraspecific variation in a generalist herbivore accounts for differential induction and impact of host plant defences. Proc R Soc B 275:443-452. https://doi.org/10.1098/rspb.2007.1277

Kanto T, Matsuura K, Yamada M, Usami T, Amemiya Y (2009) UV radiation for control of strawberry powdery mildew. Acta Hortic 842:359-362. https://doi.org/10.17660/ActaHortic .2009 .842 .68

Kanto T, Matsuura K, Ogawa T, Usami T, Amemiya Y (2011) Control of strawberry powdery mildew by UV-B radiation. Plant Prot 65:28-32 (in Japanese)

Kanto T, Matsuura K, Ogawa T, Yamada M, Ishiwata M, Usami T, Amemiya Y (2014) A new UV-B lighting system controls powdery mildew of strawberry. Acta Hortic 1049:655-660. https:// doi.org/10.17660/ActaHortic.2014.1049.101
Kawaguchi S, Manabe Y, Sugawara T, Osakabe M (2016) Imaginal feeding for progression of diapause phenotype in the two-spotted spider mite (Acari: Tetranychidae). Environ Entomol 45:1568 1573. https://doi.org/10.1093/ee/nvw127

Kelner A (1951) Action spectra for photoreactivation of ultravioletirradiated Escherichia coli and Streptomyces griseus. J Gen Physiol 34:835-852. https://doi.org/10.1085/jgp.34.6.835

Kiritani K (2012) The low development threshold temperature and the thermal constant in insects and mites in Japan ( $2^{\text {nd }}$ edition). Bull Natl Inst Agro Environ Sci 31:1-74

Kiritani K (2013) Different effects of climate change on the population dynamics of insects. Appl Entomol Zool 48:97-104. https://doi. org/10.1007/s13355-012-0158-y

Kishimoto H, Ohira Y, Adachi I (2014) Effect of different plant pollens on the development and oviposition of seven native phytoseiid species (Acari: Phytoseiidae) in Japan. Appl Entomol Zool 49:19-25. https://doi.org/10.1007/s13355-013-0218-y

Kobayashi M, Kanto T, Fujikawa T, Yamada M, Ishiwata M, Satou M, Hisamatsu T (2013) Supplemental UV radiation controls rose powdery mildew disease under the greenhouse conditions. Environ Control Biol 51:157-163. https://doi.org/10.2525/ecb.51.157

Kojima T, Sakuma M, Fukui M, Kuwahara Y (2003) Spatial orientation of the mould mite, Tyrophagus putrescentiae (Schrank) (Acarina: Acaridae), in the computer-programmed olfactory field. J Acarol Soc Jpn 12:93-102. https://doi.org/10.2300/acari.12.93

Kootstra A (1994) Protection from UV-B-induced DNA damage by flavonoids. Plant Mol Biol 26:771-774. https://doi.org/10.1007/ bf00013762

Kouwenberg JHM, Browman HI, Cullen JJ, Davis RF, St-Pierre J-F, Runge JA (1999a) Biological weighting of ultraviolet (280-400 $\mathrm{nm}$ ) induced mortality in marine zooplankton and fish. I. Atlantic cod (Gadus morhua) eggs. Mar Biol 134:269-284. https://doi. org/10.1007/s002270050545

Kouwenberg JHM, Browman HI, Cullen JJ, Davis RF, St-Pierre J-F (1999b) Biological weighting of ultraviolet (280-400 nm) induced mortality in marine zooplankton and fish. II. Calanus finmarchicus (Copepoda) eggs. Mar Biol 134:285-293. https:// doi.org/10.1007/s002270050546

Koveos DS, Suzuki T, Terzidou A, Kokkari A, Floros G, Damos P, Kouloussis NA (2017) Egg hatching response to a range of ultraviolet-B (UV-B) radiation doses for four predatory mites and the herbivorous spider mite Tetranychus urticae. Exp Appl Acarol 71:35-46. https://doi.org/10.1007/s10493-016-0102-x

Kuhlmann F, Müller C (2009a) Development-dependent effects of UV radiation exposure on broccoli plants and interactions with herbivorous insects. Environ Exp Bot 66:61-68. https://doi. org/10.1016/j.envexpbot.2009.01.001

Kuhlmann F, Müller C (2009b) Independent responses to ultraviolet radiation and herbivore attack in broccoli. J Exp Bot 60:34673475. https://doi.org/10.1093/jxb/erp182

Kunz BA, Cahill DM, Mohr PG, Osmond MJ, Vonarx EJ (2006) Plant responses to UV radiation and links to pathogen resistance. Int Rev Cytol 255:1-40. https://doi.org/10.1016/S0074 -7696(06)55001-6

Lavola A, Julkunen-Tiitto R, Roininen H, Aphalo P (1998) Host-plant preference of an insect herbivore mediated by UV-B and $\mathrm{CO}_{2}$ in relation to plant secondary metabolites. Biochem Syst Ecol 26:1-12. https://doi.org/10.1016/S0305-1978(97)00104-X

Lawrence KP, Young AR, Diffey BL, Norval M (2020) The impact of solar ultraviolet radiation on fish: immunomodulation and photoprotective strategies. Fish Fish 21:104-119. https://doi. org/10.1111/faf.12420

Lu F, Chen Q, Chen Z, Lu H, Xu X, Jing F (2014) Effects of heat stress on development, reproduction and activities of protective enzymes in Mononychellus mcgregori. Exp Appl Acarol 63:267284. https://doi.org/10.1007/s10493-014-9784-0 
MacFadyen EJ, Williamson CE, Grad G, Lowery M, Jeffrey WH, Mitchell DL (2004) Molecular response to climate change: temperature dependence of UV-induced DNA damage and repair in the freshwater crustacean Daphnia pulicaria. Global Change Biol 10:408-416. https://doi.org/10.1111/j.1529-8817.2003.00750.x

Mangoli S, Rath D, Goswami M, Jawali N (2014) Increased ultraviolet radiation sensitivity of Escherichia coli grown at low temperature. Can J Microbiol 60:327-331. https://doi.org/10.1139/ cjm-2013-0874

Manova V, Georgieva R, Borisov B, Stoilov L (2016) Efficient removal of cyclobutane pyrimidine dimers in barley: differential contribution of light-dependent and dark DNA repair pathways. Physiol Plant 158:236-253. https://doi.org/10.1111/ppl.12446

Masui S, Katai Y, Yamada M, Aoki S, Sakurai T, Osakabe M (2013) Effects of UV-B radiation on the reproduction of Tetranychus ludeni and the growth of melon plants. Ann Rept Kansai P1 Prot 55:37-41 (in Japanese with English summary)

Mazza CA, Izaguirre MM, Curiale J, Ballaré CL (2010) A look into the invisible: ultraviolet-B sensitivity in an insect (Caliothrips phaseoli) revealed through a behavioural action spectrum. Proc R Soc B 277:367-373. https://doi.org/10.1098/rspb.2009.1565

McEnroe WE (1961) The control of water loss by the twospotted spider mite (Tetranychus telarius). Ann Entomol Soc Am 54:883-887. https://doi.org/10.1093/aesa/54.6.883

Meador JA, Baldwin AJ, Catala P, Jeffrey WH, Joux F, Moss JA, Pakulski JD, Stevens R, Mitchell DL (2009) Sunlight-induced DNA damage in marine micro-organisms collected along a latitudinal gradient from $70^{\circ} \mathrm{N}$ to $68^{\circ} \mathrm{S}$. Photochem Photobiol 85:412-420. https://doi.org/10.1111/j.1751-1097.2008.00462 . $\mathrm{x}$

Metcalf RL, Newell IM (1962) Investigation of the biochronies of mites. Ann Entomol Soc Am 55:350-353. https://doi. org/10.1093/aesa/55.3.350

Mitchell DL, Nairn RS (1989) The biology of the (6-4) photoproduct. Photochem Photobiol 49:805-819. https://doi. org/10.1111/j.1751-1097.1989.tb05578.x

Mitchell DL, Adams-Deutsch T, Olson MH (2009) Dose dependence of DNA repair in rainbow trout (Oncorhynchus mykiss) larvae exposed to UV-B radiation. Photochem Photobiol Sci 8:75-81. https://doi.org/10.1039/B807469K

Morimoto K, Furuichi H, Yano S, Osakabe M (2006) Web-mediated interspecific competition among spider mites. J Econ Entomol 99:678-684. https://doi.org/10.1093/jee/99.3.678

Morison SA, Cramp RL, Alton LA, Franklin CE (2020) Cooler temperatures slow the repair of DNA damage in tadpoles exposed to ultraviolet radiation: implications for amphibian declines at high altitude. Glob Change Biol 26:1225-1234. https://doi. org/10.1111/gcb.14837

Munakata N, Morohoshi F, Hieda K, Suzuki K, Furusawa Y, Shimura H, Ito T (1996) Experimental correspondence between spore dosimetry and spectral photometry of solar ultraviolet radiation. Photochem Photobiol 63:74-78. https://doi. org/10.1111/j.1751-1097.1996.tb02994.x

Murata Y, Osakabe M (2013) The Bunsen-Roscoe reciprocity law in ultraviolet-B-induced mortality of the two-spotted spider mite Tetranychus urticae. J Insect Physiol 59:241-247. https://doi. org/10.1016/j.jinsphys.2012.11.008

Murata Y, Osakabe M (2014) Factors affecting photoreactivation in UVB-irradiated herbivorous spider mite (Tetranychus urticae). Exp Appl Acarol 63:253-265. https://doi.org/10.1007/s1049 3-014-9773-3

Murata Y, Osakabe M (2017a) Photo-enzymatic repair of UVB-induced DNA damage in the two-spotted spider mite Tetranychus urticae. Exp Appl Acarol 71:15-34. https://doi.org/10.1007/s1049 3-016-0100-z
Murata Y, Osakabe M (2017b) Developmental phase-specific mortality after ultraviolet-B radiation exposure in the two-spotted spider mite. Environ Entomol 46:1448-1455. https://doi.org/10.1093/ ee/nvx 169

Naegele JA, McEnroe WD, Soans AB (1966) Spectral sensitivity and orientation response of the two-spotted spider mite, Tetranychus urticae Koch, from $350 \mathrm{~m} \mu$ to $700 \mathrm{~m} \mu$. J Insect Physiol 12:11871195. https://doi.org/10.1016/0022-1910(66)90131-4

Nahon S, Porras VAC, Pruski AM, Charles F (2009) Sensitivity to UV radiation in early life stages of the Mediterranean Sea urchin Sphaerechinus granularis (Lamarck). Sci Total Environ 407:1892-1900. https://doi.org/10.1016/j.scitotenv.2008.11.044

Nakai K, Murata Y, Osakabe M (2018) Effects of low temperature on spider mite control by intermittent ultraviolet-B irradiation for practical use in greenhouse strawberries. Environ Entomol 47:140-147. https://doi.org/10.1093/ee/nvx179

Nakano T, Hagihara T, Okayama K (1992) Decreased sensitivity of strawberry powdery mildew to ergosterol biosynthesis inhibitors. Bull Nara Agri Expt Sta 23:27-32 (in Japanese with English summary)

Neugart S, Schreiner M (2018) UVB and UVA as eustressors in horticultural and agricultural crops. Sci Hortic (Amsterdam) 234:370-381. https://doi.org/10.1016/j.scienta.2018.02.021

Ohtsuka K, Osakabe M (2009) Deleterious effects of UV-B radiation on herbivorous spider mites: they can avoid it by remaining on lower leaf surfaces. Environ Entomol 38:920-929. https://doi. org/10.1603/022.038.0346

Onzo A, Hanna R, Sabelis MW (2009) Within-plant migration of the predatory mite Typhlodromalus aripo from the apex to the leaves of cassava: response to day-night cycle, prey location and prey density. J Insect Behav 22:186-195. https://doi.org/10.1007/ s10905-008-9164-x

Onzo A, Sabelis MW, Hanna R (2010) Effects of ultraviolet radiation on predatory mites and the role of refuges in plant structures. Environ Entomol 39:695-701. https://doi.org/10.1603/EN09206

Osakabe M (1965) Seasonal fluctuation of population density of the tea red spider mite, Tetranychus kanzawai Kishida, in the tea plantation. Jpn J Appl Entomol Zool 9:206-210 (in Japanese with English summary)

Osakabe M (1988) Relationships between food substances and developmental success in Amblyseius sojaensis Ehara (Acarina: Phytoseiidae). Appl Entomol Zool 23:45-51. https://doi.org/10.1303/ aez.23.45

Osakabe M, Inoue K, Ashihara W (1987) Effect of Amblyseius sojaensis Ehara (Acarina: Phytoseiidae) as a predator of Panonychus citri (McGregor) and Tetranychus kanzawai Kishida (Acarina: Tetranychidae). Appl Entomol Zool 22:594-599. https://doi. org/10.1303/aez.22.594

Osakabe M, Hongo K, Funayama K, Osumi S (2006) Amensalism via webs causes unidirectional shifts of dominance in spider mite communities. Oecologia 150:496-505. https://doi.org/10.1007/ s00442-006-0560-7

Osakabe M, Uesugi R, Goka K (2009) Evolutionary aspects of acaricide-resistance development in spider mites. Psyche J Entomol 2009:947439. https://doi.org/10.1155/2009/947439

Ozawa R, Endo H, Iijima M, Sugimoto K, Takabayashi J, Gotoh T, Arimura G (2017) Intraspecific variation among Tetranychid mites for ability to detoxify and to induce plant defenses. Sci Rep 7:43200. https://doi.org/10.1038/srep43200

Pakker H, Martins RST, Boelen P, Buma AGJ (2000) Effects of temperature on the photoreactivation of ultraviolet-B-induced DNA damage in Palmaria palmate (Rhodophyta). J Phycol 36:334341. https://doi.org/10.1046/j.1529-8817.2000.99087.x

Paul ND, Gwynn-Jones D (2003) Ecological roles of solar UV radiation: towards an integrated approach. Trends Ecol Evol 18:48-55. https://doi.org/10.1016/S0169-5347(02)00014-9 
Peccia J, Hernandez M (2001) Photoreactivation in airborne Mycobacterium parafortuitum. Appl Environ Microbiol 67:4225-4232. https://doi.org/10.1128/AEM.67.9.4225-4232.2001

Perring TM, Holtzer TO, Kalisch JA, Norman JM (1984) Temperature and humidity effects on ovipositional rates, fecundity, and longevity of adult females Banks grass mites (Acari: Tetranychidae). Ann Entomol Soc Am 77:581-586. https://doi.org/10.1093/ aesa/77.5.581

Pescheck F (2019) UV-A screening in Cladophora sp. lowers internal UV-A availability and photoreactivation as compared to non-UV screening in Ulva intestinalis. Photochem Photobiol Sci 18:413423. https://doi.org/10.1039/C8PP00432C

Pfeifer GP (2020) Mechanisms of UV-induced mutations and skin cancer. Genome Instab Dis 1:99-113. https://doi.org/10.1007/ s42764-020-00009-8

Price CE (1980) A review of the factors influencing the penetration of pesticides through plant leaves. In: Cutler DF, Alvin KL, Price CE (eds) Plant cuticle, papers presented at an international symposium organized by the Linnean Society of London, held at Burlington House, London, 8-11 September 1980. Academic Press, London, pp 237-252

Putman WL (1965) Paper chromatography to detect predation on mites. Can Entomol 97:435-441. https://doi.org/10.4039/Ent97 435-4

Rastogi RP, Richa, Kumar A, Tyagi MB, Sinha RP (2010) Molecular mechanisms of ultraviolet radiation-induced DNA damage and repair. J Nucleic Acids 2010:592980. https://doi. org/10.4061/2010/592980

Rêgo AS, Teodoro AV, Maciel AGS, Sarmento RA (2013) Relative contribution of biotic and abiotic factors to the population density of the cassava green mite, Mononychellus tanajoa (Acari: Tetranychidae). Exp Appl Acarol 60:479-484. https:// doi.org/10.1007/s10493-013-9667-9

Riley RL, Kaufman JE (1972) Effect of relative humidity on the inactivation of airborne Serratia marcescens by ultraviolet radiation. Appl Environ Microbiol 23:1113-1120 (PMID: 4557562)

Rousseaux MC, Scopel A, Searles PS, Caldwell MM, Sala OE, Ballaré CL (2001) Responses to solar ultraviolet-B radiation in a shrub-dominated natural ecosystem of Tierra del Fuego (southern Argentina). Glob Change Biol 7:467-478. https://doi.org/ 10.1046/j.1365-2486.2001.00413.x

Rousseaux MC, Julkunen-Tiitto R, Searles PS, Scopel AL, Aphalo PJ, Ballaré CL (2004) Solar UV-B radiation affects leaf quality and insect herbivory in the southern beech tree Nothofagus antarctica. Oecologia 138:505-512. https://doi.org/10.1007/ s00442-003-1471-5

Sakai Y, Osakabe M (2010) Spectrum-specific damage and solar ultraviolet radiation avoidance in the two-spotted spider mite. Photochem Photobiol 86:925-932. https://doi.org/10.111 1/j.1751-1097.2010.00739.x

Sakai Y, Sudo M, Osakabe M (2012a) A comparison of the effects of gravity and the nutritional advantage of leaf surfaces on fecundity in the two-spotted spider mite (Acari: Tetranychidae). J Acarol Soc Jpn 21:1-6. https://doi.org/10.2300/acari.21.1

Sakai Y, Sudo M, Osakabe M (2012b) Seasonal changes in the deleterious effects of solar ultraviolet-B radiation on eggs of the twospotted spider mite, Tetranychus urticae (Acari: Tetranychidae). Appl Entomol Zool 47:67-73. https://doi.org/10.1007/ s13355-011-0090-6

Sancar A (2003) Structure and function of DNA photolyase and cryptochome blue-light photoreceptors. Chem Rev 103:22032237. https://doi.org/10.1021/cr0204348

Santos CD (2005) Photoreactivation of ultraviolet-B damage in Tyrophagus putrescentiae (Acari: Acaridae) and Tetranychus urticae (Acari: Tetranychidae). Int J Acarol 31:429-431. https ://doi.org/10.1080/01647950508683685
Shahidi F, Chandrasekara A (2010) Hydroxycinnamates and their in vitro and in vivo antioxidant activities. Phytochem Rev 9:147-170. https://doi.org/10.1007/s11101-009-9142-8

Shinmen T, Yano S, Osakabe M (2010) The predatory mite Neoseiulus womersleyi (Acari: Phytoseiidae) follows extracts of trails left by the two-spotted spider mite Tetranychus urticae (Acari: Tetranychidae). Exp Appl Acarol 52:111-118. https:// doi.org/10.1007/s10493-010-9356-x

Shiroya T, McElroy DE, Sutherland BM (1984) An action spectrum of photoreactivating enzyme from sea urchin eggs. Photochem Photobiol 40:749-751. https://doi. org/10.1111/j.1751-1097.1984.tb04647.x

Short BD, Janisiewicz W, Takeda F, Leskey TC (2018) UV-C irradiation as a management tool for Tetranychus urticae on strawberries. Pest Manag Sci 74:2419-2423. https://doi.org/10.1002/ ps. 5045

Sinha RP, Häder DP (2002) UV-induced DNA damage and repair: a review. Photochem Photobiol Sci 1:225-236. https://doi. org/10.1039/B201230H

Slieman T, Nicholson WL (2000) Artificial and solar UV radiation induces strand breaks and cyclobutene pyrimidine dimers in Bacillus subtilis spore DNA. Appl Environ Microbiol 66:199205. https://doi.org/10.1128/AEM.66.1.199-205.2000

Sombardier A, Dufour MC, Blancard D, Corio-Costet MF (2010) Sensitivity of Podosphaera aphanis isolates to DMI fungicides: distribution and reduced cross-sensitivity. Pest Manag Sci 66:35-43. https://doi.org/10.1002/ps.1827

Spaethe J, Briscoe AD (2005) Molecular characterization and expression of the UV opsin in bumblebees: three ommatidial subtypes in the retina and a new photoreceptor organ in the lamina. J Exp Biol 208:2347-2361. https://doi.org/10.1242/jeb.01634

Sudo M, Osakabe M (2011) Do plant mites commonly prefer the underside of leaves? Exp Appl Acarol 55:25-38. https://doi. org/10.1007/s10493-011-9454-4

Sudo M, Osakabe M (2013) Stellate hairs on leaves of a deciduous shrub Viburnum erosum var. punctatum (Adoxaceae) effectively protect Brevipalpus obovatus (Acari: Tenuipalpidae) eggs from the predator Phytoseius nipponicus (Acari: Phytoseiidae). Exp Appl Acarol 60:299-311. https://doi.org/10.1007/s1049 3-012-9648-4

Sudo M, Osakabe M (2015) Joint effect of solar UVB and heat stress on the seasonal change of egg hatching success in the herbivorous false spider mite (Acari: Tenuipalpidae). Environ Entomol 44:1605-1613. https://doi.org/10.1093/ee/nvv131

Sugeno W, Iwasaki Y, Hachiya Y (2018) Irradiation with UV-B fluorescent bulbs suppresses strawberry powdery mildew. Acta Hortic 1227:549-554. https://doi.org/10.17660/ActaHortic .2018 .1227 .69

Sugioka N, Kawakami M, Hirai N, Osakabe M (2018) A pollen diet confers ultraviolet-B resistance in phytoseiid mites by providing antioxidants. Front Ecol Evol 6:133. https://doi.org/10.3389/ fevo.2018.00133

Suthaparan A, Stensvand A, Solhaug KA, Mortensen LM, Seem RC (2012) Suppression of powdery mildew (Podosphaera pannosa) in greenhouse roses by brief exposure to supplemental UV-B radiation. Plant Dis 96:1653-1660. https://doi.org/10.1094/ PDIS-01-12-0094-RE

Suthaparan A, Stensvand A, Solhaug KA, Torre S, Telfer KH, Ruud AK, Mortensen LM, Gadoury DM, Seem RC, Gislerød HR (2014) Suppression of cucumber powdery mildew by supplemental UV-B radiation in greenhouses can be augmented or reduced by background radiation quality. Plant Dis 98:1349-1357. https ://doi.org/10.1094/PDIS-03-13-0222-RE

Suthaparan A, Solhaug KA, Stensvand A, Gislerød HR (2016a) Determination of UV action spectra affecting the infection process of 
Oidium neolycopersici, the cause of tomato powdery mildew. J Photochem Photobiol B 156:41-49. https://doi.org/10.1016/j. jphotobiol.2016.01.009

Suthaparan A, Solhaug KA, Bjugstad N, Gislerød HR, Gadoury DM, Stensvand A (2016b) Suppression of powdery mildews by UV-B: application frequency and timing, dose, reflectance, and automation. Plant Dis 100:1643-1650. https://doi.org/10.1094/ PDIS-12-15-1440-RE

Suthaparan A, Solhaug KA, Stensvand A, Gislerød HR (2017) Daily light integral and day light quality: potentials and pitfalls of nighttime UV treatments on cucumber powdery mildew. J Photochem Photobiol B 175:141-148. https://doi.org/10.1016/j.jphot obiol.2017.08.041

Suthaparan A, Pathak R, Solhaug KA, Gislerød HR (2018) Wavelength dependent recovery of UV-mediated damage: tying up the loose ends of optical based powdery mildew management. J Photochem Photobiol B 178:631-640. https://doi.org/10.1016/j.jphot obiol.2017.12.018

Suzuki T, Watanabe M, Takeda M (2009) UV tolerance in the twospotted spider mite, Tetranychus urticae. J Insect Physiol 55:649654. https://doi.org/10.1016/j.jinsphys.2009.04.005

Suzuki T, Kojima T, Takeda M, Sakuma M (2013) Photo-orientation regulates seasonal habitat selection in the two-spotted spider mite, Tetranychus urticae. J Exp Biol 216:977-983. https://doi. org/10.1242/jeb.079582

Suzuki T, Yoshioka Y, Tsarsitalidou O, Ntalia V, Ohno S, Ohyama K, Kitashima Y, Gotoh T, Takeda M, Koveos D (2014) An LED-based UV-B irradiation system for tiny organisms: system description and demonstration experiment to determine the hatchability of eggs from four Tetranychus spider mite species from Okinawa. J Insect Physiol 62:1-10. https://doi. org/10.1016/j.jinsphys.2014.01.005

Tachi F, Osakabe M (2012) Vulnerability and behavioral response to ultraviolet radiation in the components of a foliar mite preypredator system. Naturwissenschaften 99:1031-1038. https://doi. org/10.1007/s00114-012-0984-3

Tachi F, Osakabe M (2014) Spectrum-specific UV egg damage and dispersal responses in the phytoseiid predatory mite Neoseiulus californicus (Acari: Phytoseiidae). Environ Entomol 43:787794. https://doi.org/10.1603/EN13336

Takahashi S, Nakajima N, Saji H, Kondo N (2002) Diurnal change of cucumber CPD photolyase gene (CsPHR) expression and its physiological role in growth under UV-B irradiation. Plant Cell Physiol 43:342-349. https://doi.org/10.1093/pcp/pcf038

Tanaka M, Yase J, Aoki S, Sakurai T, Kanto T, Osakabe M (2016) Physical control of spider mites using ultraviolet-B with light reflection sheets in greenhouse strawberries. J Econ Entomol 109:1758-1765. https://doi.org/10.1093/jee/tow096

Tegelberg R, Julkunen-Tiitto R, Aphalo PJ (2004) Red: far-red light ratio and UV-B radiation: their effects on leaf phenolics and growth of silver birch seedlings. Plant Cell Environ 27:10051013. https://doi.org/10.1111/j.1365-3040.2004.01205.x

Thoma F (1999) Light and dark in chromatin repair: repair of UVinduced DNA lesions by photolyase and nucleotide excision repair. EMBO J 18:6585-6598. https://doi.org/10.1093/emboj $/ 18.23 .6585$

Todo T, Ryo H, Yamamoto K, Toh H, Inui T, Ayaki H, Nomura T, Ikenaga M (1996) Similarity among the Drosophila (6-4)photolyase, a human photolyase homolog, and the DNA photolyaseblue-light photoreceptor family. Science 272:109-112. https:// doi.org/10.1126/science.272.5258.109

Tomimori D, Hosokawa M, Aoki S, Osakabe M (2020) Effects of growth phase and ultraviolet-B pretreatment in perilla leaves on the two-spotted spider mite. Environ Entomol 49:886-894. https ://doi.org/10.1093/ee/nvaa055
Van Leeuwen T, Vontas J, Tsagkarakou A, Dermauw W, Tirry L (2010) Acaricide resistance mechanisms in the two-spotted spider mite Tetranychus urticae and other importance Acari: a review. Insect Biochem Mol Biol 40:563-572. https://doi.org/10.1016/j. ibmb.2010.05.008

Van Leeuwen T, Tirry L, Yamamoto A, Nauen R, Dermauw W (2015) The economic importance of acaricides in the control of phytophagous mites and an update on recent acaricide mode of action research. Pestic Biochem Physiol 121:12-21. https://doi. org/10.1016/j.pestbp.2014.12.009

Van Uitregt VO, Wilson RS, Franklin CE (2007) Cooler temperatures increase sensitivity to ultraviolet $\mathrm{B}$ radiation in embryos and larvae of the frog Limnodynastes peronii. Glob Change Biol 13:1114-1121. https://doi.org/10.1111/j.1365-2486.2007.01353 .X

Van Zon AQ, Overmeer WP, Veerman A (1981) Carotenoids function in photoperiodic induction of diapause in a predacious mite. Science 213:1131-1133. https://doi.org/10.1126/scien ce.213.4512.1131

Veerman A (1972) Carotenoids of wild-type and mutant strains of Tetranychus pacificus McGregor (Acari: Tetranychidae). Comp Biochem Physiol B Biochem Mol Biol 42:329-340. https://doi. org/10.1016/0305-0491(72)90277-5

Veerman A (1974a) Carotenoid metabolism in Tetranychus urticae Koch (Acari: Tetranychidae). Comp Biochem Physiol B Comp Biochem 47:101-116. https://doi.org/10.1016/03050491(74)90095-9

Veerman A (1974b) The carotenoid pigments of Schizonobia sycophanta Womersley (Acari: Tetranychidae). Comp Biochem Physiol B Comp Biochem 48:321-327. https://doi.org/10.1016/03050491(74)90267-3

Veerman A (1980) Functional involvement of carotenoids in photoperiodic induction of diapause in the spider mite, Tetranychus urticae. Physiol Entomol 5:291-300. https://doi. org/10.1111/j.1365-3032.1980.tb00237.x

Veerman A (1992) Diapause in phytoseiid mites: a review. Exp Appl Acarol 14:1-60. https://doi.org/10.1007/BF01205351

Wahl M (2008) Ecological modulation of environmental stress: interactions between ultraviolet radiation, epibiotic snail embryos, plants and herbivores. J Anim Ecol 77:549-557. https://doi.org/ 10.1111/j.1365-2656.2007.01352.x

Wang S, Xie B, Yin L, Duan L, Li Z, Eneji AE, Tsuji W, Tsunekawa A (2010) Increased UV-B radiation affects the viability, reactive oxygen species accumulation and antioxidant enzyme activities in maize (Zea mays L.) pollen. Photochem Photobiol 86:110 116. https://doi.org/10.1111/j.1751-1097.2009.00635.x

Weber S (2005) Light-driven enzymatic catalysis of DNA repair: a review of recent biophysical studies on photolyase. Biochim Biophys Acta 1707:1-23. https://doi.org/10.1016/j.bbabi o.2004.02.010

Weintraub PG, Kleitman S, Alchanatis V, Palevsky E (2007) Factors affecting the distribution of a predatory mite on greenhouse sweet pepper. Exp Appl Acarol 42:23-35. https://doi.org/10.1007/ s10493-007-9077-y

Wiegand MD, Young DLW, Gajda BM, Thuen DJM, Rittberg DAH, Huebner JD, Loadman NL (2004) Ultraviolet light-induced impairment of goldfish embryo development and evidence for photorepair mechanisms. J Fish Biol 64:1242-1256. https://doi. org/10.1111/j.0022-1112.2004.00388.x

Williamson CE, Grad G, De Lange HJ, Gilroy S, Karapelou DM (2002) Temperature-dependent ultraviolet responses in zooplankton: implications of climate change. Limnol Oceanogr 47:1844-1848. https://doi.org/10.4319/1o.2002.47.6.1844

Wübben DL (2000) UV-induced mortality of zoea I larvae of brown shrimp Crangon crangon (Linnaeus, 1758). J Plankton Res 22:2095-2104. https://doi.org/10.1093/plankt/22.11.2095 
Wyenandt CA, McGrath MT, Everts KL, Rideout SL, Gugino BK, Kleczewski N (2018) Fungicide resistance management guidelines for cucurbit downy and powdery mildew control in the mid-Atrantic and northeast regions of the United States in 2018. Plant Health Prog 19:34-36. https://doi.org/10.1094/ PHP-12-17-0077-BR

Yamamoto A (2012) Problems of the insecticide resistance management for sustained insect pest control. J Pestic Sci 37:392-398. https://doi.org/10.1584/jpestics.W12-20 (in Japanese)

Yanagita H (2019) Current and future integrated pest management strategies for Tetranychus urticae (Acari: Tetranychidae) in strawberry forcing culture: current status and future IPM strategies in Fukuoka Prefecture, Japan. Jpn J Appl Entomol Zool 63:1-12. https://doi.org/10.1303/jjaez.2019.1 (in Japanese with an English summary)

Yang L, Huang H, Wang J (2010) Antioxidant responses of citrus red mite, Panonychus citri (McGregor) (Acari: Tetranychidae), exposed to thermal stress. J Insect Physiol 56:1871-1875. https ://doi.org/10.1016/j.jinsphys.2010.08.006

Yano S, Osakabe M (2009) Do spider mite-infested plants and spider mite trails attract predatory mites? Ecol Res 24:1173-1178. https ://doi.org/10.1007/s11284-009-0598-1

Yin W-D, Hoffmann AA, Gu X-B, Ma C-S (2018) Behavioral thermoregulation in a small herbivore avoids direct UVB damage.
J Insect Physiol 107:276-283. https://doi.org/10.1016/j.jinsp hys.2017.12.002

Yoshioka Y, Gotoh T, Suzuki T (2018) UV-B susceptibility and photoreactivation in embryonic development of the two-spotted spider mite, Tetranychus urticae. Exp Appl Acarol 75:155-166. https:// doi.org/10.1007/s10493-018-0263-x

Yuan L, Osakabe M (2020) Dose-response and temperature dependence of the mortality of spider mite and predatory mite eggs caused by daily nighttime ultraviolet-B irradiation. Photochem Photobiol 96:877-882. https://doi.org/10.1111/php.13204

Yuan L, Mori S, Haruyama N, Hirai N, Osakabe M (2020) Strawberry pollen as a source of UV-B protection ingredients for the phytoseiid mite Neoseiulus californicus (Acari: Phytoseiidae). Pest Manag Sci. https://doi.org/10.1002/ps.6089 (in press)

Žilić S, Vančetović J, Janković M, Maksimović V (2014) Chemical composition, bioactive compounds, antioxidant capacity and stability of floral maize (Zea mays L.) pollen. J Funct Foods 10:65-74. https://doi.org/10.1016/j.jff.2014.05.007

Publisher's Note Springer Nature remains neutral with regard to jurisdictional claims in published maps and institutional affiliations. 